\title{
Climatic breadth of calling behaviour in two widespread Neotropical frogs: insights from humidity extremes
}

\author{
Bonnefond Anaïs ${ }^{1}$, Courtois Elodie A. ${ }^{1}$, Sueur Jérôme ${ }^{2}$, Sugai Larissa Sayuri Moreira ${ }^{3,4}$, \\ Llusia Diego 4,5,6, *
}

1 LEEISA UMSR 3456CNRS - UG - Ifremer; Centre de recherche Montabo 275 Route de Montabo BP 7062097300 Cayenne French Guiana

2 Institut de SystématiqueÉvolution, Biodiversité (ISYEB), Muséum national d'Histoire naturelle, CNRS, Sorbonne Université, EPHE 57 rue Cuvier 75005 Paris France

3 Instituto de Biociências Universidade Estadual Paulista (UNESP) 13506-900 Rio Claro São Paulo, Brazil

${ }^{4}$ Departamento de EcologíaTerrestrial Ecology Group Universidad Autónoma de Madrid (UAM), C/

Darwin 2, E-28049, Ciudad Universitaria de Cantoblanco Madrid Spain

${ }^{5}$ Centro de Investigación en Biodiversidad y Cambio Global (CIBC-UAM) Universidad Autónoma de Madrid, C/ Darwin 2, E-28049, Ciudad Universitaria de Cantoblanco Madrid, Spain

${ }^{6}$ Departamento de EcologiaLaboratório de Herpetologia e Comportamento Animal, Instituto de Ciências Biológicas, Universidade Federal de Goiás (UFG) Avenida Esperança 74001-970 Goiânia GO ,Brazil

*Corresponding author : Diego Llusia, email address : diego.llusia@uam.es

\begin{abstract}
:
Climate change is severely altering precipitation regimes at local and global scales, yet the capacity of species to cope with these changes has been insufficiently examined. Amphibians are globally endangered and particularly sensitive to moisture conditions. For mating, most amphibian species rely on calling behaviour, which is a key weather-dependent trait. Using passive acoustics, we monitored the calling behaviour of two widely distributed Neotropical frogs in 12 populations located at the humidity extremes but thermal mean of the species distribution. Based on 2,554 hours of recordings over a breeding season, we found that both the arboreal species Boana raniceps and the aquatic species Pseudis paradoxa exhibited calling behaviour at a wide range of relative humidity. Calling humidity was significantly lower in conspecific populations subjected to drier conditions, while calling temperature did not differ between populations or species. Overall, no variation in climatic breadth was observed between large and small choruses, and calling behaviour was scarcely detected during the driest, hottest and coldest potential periods of breeding. Our results showed that calling humidity of the studied species varies according to the precipitation regime, suggesting that widespread Neotropical anurans may have the capacity to exhibit sexual displays in different climatic environments. Regardless of the underlying mechanism (plasticity or local adaptation), which should be determined by common garden experiments, a wide and population-specific climatic breadth of calling behaviour may assist species to deal with changing humidity conditions. To our knowledge, this is the first study to explore the response capacity of anurans to perform calling behaviour under contrasting precipitation regimes.
\end{abstract}


Keywords: Acoustic communication, Amphibians, Climate change, Hylidae, Paper type: Primary Research Articles, Passive acoustic monitoring, Precipitation, Relative humidity, Reproduction 


\section{INTRODUCTION}

Human-induced climate change is severely altering both thermal and precipitation regimes worldwide (e.g. Huntington, 2006; IPCC, 2013; IPCC, 2007; Zhang et al., 2007), modifying average temperatures and the volume and temporal patterns of rainfall at local and global scales (Coffel, Horton \& Sherbinin, 2018; New, Todd, Hulme \& Jones, 2001; Río, Herrero, Fraile \& Penas, 2011; Smith, Yin \& Gruber, 2006). The environmental changes that species are facing potentially impact their distribution (Araújo, Thuiller \& Pearson, 2006; Hickling, Roy, Hill, Fox \& Thomas, 2006; Wilson, Gutiérrez, Gutiérrez, Martínez, Agudo \& Monserrat, 2005), phenology (Dunn \& Møller, 2014; Llusia, Márquez, Beltrán, Moreira \& Amaral, 2013a; Oseen \& Wassersug, 2002), trophic interactions (Gilman, Urban, Tewksbury, Gilchrist \& Holt, 2010; Ockendon et al., 2014; Thackeray et al., 2010) and, in turn, survival (Cowley \& Siriwardena, 2005; Shrader, Pimm \& van Aarde, 2010; Sinervo et al., 2010). The effects of global warming on animals have received growing attention (Angilletta, 2009; Gunderson \& Stillman, 2015; Huey et al., 2012; Sinervo et al., 2010), yet the consequences of changing precipitation regimes are still largely unknown (Weltzin et al., 2003).

Amphibians are particularly vulnerable to changes in rainfall and moisture conditions given their high dependence to water at various stages of their life cycle (Feder \& Burggren, 1992; Wells \& Schwartz, 2007), and climate-driven population declines in several taxa have been documented by long-term studies (e.g. Burrowes, Joglar \& Green, 2004; Scheele, Driscoll, Fischer \& Hunter, 2012). Despite the remarkable diversity of reproductive modes, amphibians mostly rely on freshwater availability for reproduction and larval development (Crump, 2015; Haddad \& Prado, 2005). Moreover, in adults, water balance is a major environmental constraint due to their water-permeable skin. Indeed, multiple adaptations have evolved in this group to reduce the risk of dehydration in terrestrial environments (McDiarmid, 1994; Wells \& Schwartz, 2007). However, extreme droughts, shortened hydroperiods, reduced soil moisture and shifts in rainfall patterns can lead to populationlevel changes in abundance (Burrowes et al., 2004; Stewart, 1995), activity level (Jansen, Schulze, Werding \& Streit, 2009) and structure (McMenamin \& Hadly, 2010) or even to local extinctions (Scheele et al., 2012).

Predicting the impact of climate change on amphibians is a pressing challenge for 
biologists. Global population declines make amphibians the most endangered vertebrate class, with more than $40 \%$ of the described species classified as threatened on the IUCN Red List (Hoffmann et al., 2010). In addition to habitat loss and emerging diseases (Collins \& Storfer, 2003; Hecnar, 1997; 0'Hanlon et al., 2018), climate change is another driver that may produce synergistic deleterious effects on amphibian populations (Bosch, Carrascal, Duran, Walker \& Fisher, 2007; D’Amen \& Bombi, 2009; Hof, Araujo, Jetz \& Rahbek, 2011). However, the link between climate change and global amphibian declines is still unclear (Beebee \& Griffiths, 2005; Li, Cohen \& Rohr, 2013; Lips, Diffendorfer, Mendelson \& Sears, 2008; Rohr, Raffel, Romansic, McCallum \& Hudson, 2008), indicating the need for new approaches and metrics for its investigation (Beebee \& Griffiths, 2005; Carey \& Alexander, 2003; Lips et al., 2008). Mechanistic models offer a promising framework, though the shortage of eco-physiological information on species constrains their application (Bovo, Navas, Tejedo, Valença \& Gouveia, 2018).

Calling behaviour is a key component of the mating strategy of most anuran amphibians, and is directly involved in sexual selection (Gerhard \& Huber, 2002; Narins, Feng, Fay \& Popper, 2007). Males typically produce advertisement and territorial calls, often forming loud choruses at breeding sites, to attract potential mates and deter competitors. Several environmental factors regulate calling and chorusing behaviour including rainfall and relative humidity (Brooke, Alford \& Schwarzkopf, 2000; Donnelly \& Guyer, 1994; Hatano, Rocha \& Sluys, 2002; Llusia et al., 2013a; Steelman \& Dorcas, 2010), temperature (Llusia et al., 2013a; Murphy, 2003; Steelman \& Dorcas, 2010), barometric pressure (Henzi, Dyson, Piper, Passmore \& Bishop, 1995; Oseen \& Wassersug, 2002) and light intensity (Almeida-Gomes, Van Sluys \& Duarte Rocha, 2007; Steelman \& Dorcas, 2010, Grant, Halliday \& Chadwick, 2013). In addition to being a widespread and weather-dependent trait and playing a crucial role in species survival, calling behaviour can also be used to monitor populations. By using emerging techniques (Sueur \& Farina, 2015) such as passive acoustic monitoring (Sugai, Silva, Ribeiro \& Llusia, 2019), phenological patterns and their relationship with weather conditions can be explored to shed light on the effects of climate on populations (Krause \& Farina, 2016; Llusia, Márquez, Beltrán, Benítez \& Amaral, 2013b; MacLaren, McCracen \& Forstner, 2018; Sueur et al., 2019). 
Widespread species generally experience a broad range of climatic conditions across their geographic distribution, making them suitable models to investigate the capacity of the species to cope with changing climatic environments. By monitoring populations located at the thermal or humidity extremes of the species range, we can estimate the climatic breadth of key traits such as calling behaviour to better understand how species respond to distinct climatic regimes. Recently, Llusia et al. (2013b) used acoustic monitoring to estimate the thermal breadth of calling behaviour in temperate anurans and showed that the studied species have the capacity to display calling behaviour at a wide range of temperatures. To our knowledge, no previous study has explored the breadth of calling behaviour in relation to moisture conditions and how anurans respond to distinct precipitation regimes.

The effect of precipitation changes may be particularly severe in open environments, such as tropical savannahs, which are largely exposed to fluctuating humidity conditions. Climate change velocity is predicted to be highest in flooded grasslands and tropical savannahs (Loarie et al., 2009), the latter of which are considered biodiversity hotspots (Silva \& Bates, 2002) and particularly threatened (Overbeck et al., 2015; Roque et al., 2016). Despite this, the impact of climate change has been less investigated in these environments compared with other tropical biomes (e.g. tropical forests).

Here, we examined the climatic breadth of calling behaviour in two widespread Neotropical anurans inhabiting savannahs, the arboreal frog Boana raniceps and the aquatic frog Pseudis paradoxa. Using passive acoustic monitoring during an entire breeding season, we recorded the calling activity of 12 populations located at the humidity extremes but thermal mean of the species distribution. Specifically, we hypothesized that widespread Neotropical frogs can perform calling behaviour under different climatic environments. According to this hypothesis, we tested the following three predictions: (i) the studied species will show calling behaviour across a wide overall range of humidity; (ii) populations located at humidity extremes will show different ranges of calling humidity; and (ii) daily and seasonal patterns of calling activity will reveal differences in calling humidity and calling temperature across species and populations. Finally, we discuss to what extent the observed responses imply mechanisms (plasticity or local adaptation) allowing species to cope with changing precipitation regimes, providing insight on the role of moisture conditions on the 
capacity of widespread species to respond to climate change.

\section{METHODS}

\section{Study species}

Pseudis paradoxa (Linnaeus, 1758) and Boana raniceps (Cope, 1862) (previously identified as Hypsiboas raniceps but changed to B. raniceps after Dubois, 2017) are Neotropical hylid frogs commonly found in open areas such as savannahs and grasslands. They are distributed across the Amazon basin and surrounding regions including Bolivia, Paraguay and northern Argentina. As geographically widespread species, they are subjected to a broad range of climatic conditions across their distribution ranges (Figs 1 and 2). Both species are sizeable frogs (Lescure \& Marty, 2000; Haddad, Toledo, Prado, Loebmann, Gasparini \& Sazima, 2013) and prolonged breeders (i.e. breeding season lasting for more 3 consecutive months), with similar reproductive mode, characterized by laying eggs in lentic water and the development of exotrophic tadpoles (Prado, Uetanabaro \& Haddad, 2005), particularly large in $P$. paradoxa (Emerson, 1988). Low genetic distances have been recorded among populations of B. raniceps throughout the range of the species (Fouquet et al., 2007; Jansen, Bloch, Schulze \& Pfenninger, 2011; Lyra, Haddad, \& Azeredo-Espin, 2017). The conspecificity of P. paradoxa populations from French Guiana and Pantanal was confirmed based on call similarity (Santana et al. 2010). Although subspecies within P. paradoxa were formerly considered to be full species (Aguiar et al., 2007), geographic and morphological data are still required to propose any taxonomical change based on genetic evidence (Aguiar et al., 2007; Garda \& Cannatella, 2007; Garda et al., 2010).

\section{Microhabitat use}

Pseudis paradoxa and Boana raniceps belong to distinct subfamilies within Hylidae, namely Pseudinae and Cophomantinae, respectively (Frost et al., 2006). Both species exhibit sharp differences in microhabitat preference. Pseudis paradoxa is an aquatic frog that inhabits marshy areas and flooded plains with stagnant water and abundant aquatic vegetation 
(Angulo \& Baldo, 2010; Lescure \& Marty, 2000). Males of P. paradoxa can be found at the edges of ponds and swamps, preferentially calling over water surfaces near floating vegetation (Bosch, De la Riva \& Márquez, 1996). Boana raniceps is an arboreal frog found on emergent macrophytes and terrestrial vegetation that surround ponds, lagoons and large river banks (La Marca, 2004). The usual calling sites of this species are branches and leaves at the top part of aquatic vegetation (Márquez, De la Riva \& Bosch, 1993; Prado, Uetanabaro \& Haddad, 2005).

\section{Advertisement calls}

Acoustic communication plays a key role in the sexual selection of the two species (Bosch et al., 1996; Höld, 1977; Márquez et al., 1993). During the breeding season, males of both species produce advertisement calls within loud choruses to attract females. The advertisement call of $P$. paradoxa is composed of pulsed notes, emitted in series of 8 notes on average, with a mean duration of $301 \mathrm{~ms}$ and a mean dominant frequency between 2,540 and 2,711 Hz (Bosch et al., 1996; Tárano, 2010). The advertisement call of B. raniceps is composed of pulsatile notes (note-centred approach; Köhler et al., 2017) emitted in series ranging from 2 to 10 notes, with a mean duration of $163 \mathrm{~ms}$ and a mean dominant frequency between $761 \mathrm{~Hz}$ and 901 Hz (Guimarães \& Bastos, 2003; Márquez et al., 1993).

\section{Study areas}

Calling activity of the studied species was monitored in two areas located at the humidity extremes of the species range (Fig. 1): (i) the littoral region between the cities of Cayenne and Kourou in French Guiana (hereafter FG) for the humid extreme and (ii) the Pantanal wetlands in the state of Mato Grosso do Sul in the central-southern region of Brazil (hereafter BR) for the dry extreme. Due to distinct climatic regimes (Peel, Finlayson \& McMahon, 2007) and hydrogeologic dynamics (Assine, 2005; Davidson et al., 2012), FG and BR are located in two different tropical biomes, the Amazonian and the Pantanal, respectively. Annual precipitation strongly differs between the two areas, reaching on average 3,075 mm in FG and 1,312 mm in BR (Fick \& Hijmans, 2017; Fig. 1). Annual mean temperature, in contrast, differs only by $0.4^{\circ} \mathrm{C}$ between the two areas $\left(25.5^{\circ} \mathrm{C}\right.$ in $\mathrm{FG}$ and 


\section{$25.1^{\circ} \mathrm{C}$ in BR; Fig. 2).}

To estimate the extremity of the precipitation and thermal regimes of each study area, IUCN polygons (IUCN et al., 2008a; IUCN et al., 2008b) and WorldClim layers (version 2.0, 5 arc-minute resolution, $\sim 10 \times 10 \mathrm{~km}$ grid cells; Fick \& Hijmans, 2017) were used to determine, respectively, the distribution range of each species and the annual precipitation and mean temperature within each range. With the $\mathrm{R}$ packages raster, sp and rgdal, we extracted temperature and precipitation values for all raster cells from the WorldClim layers using the IUCN polygons as masks to obtain the frequency distribution of these values within the range of the studied species. We then calculated the level of precipitation and thermal extremity of the two study areas (Figs 1 and 2). Precipitation extremity was defined as the proportion of the species range with an annual precipitation below and above the annual precipitation of each study area. For both species, between $96 \%$ and $98 \%$ of their distribution range (occurrence grids) had a lower annual precipitation than that of FG (i.e. $<3,075 \mathrm{~mm}$; humid extreme) and between $77 \%$ and $84 \%$ had a higher annual precipitation than that of BR (i.e. $>1,312 \mathrm{~mm}$; dry extreme; Fig. 1, Table 1). Therefore, FG and BR show a high level of precipitation extremity. Conversely, the annual mean temperature of both study areas was similar to the overall average temperature of each species range (i.e. $25.7^{\circ} \mathrm{C}$ for $P$. paradoxa and $24.8^{\circ} \mathrm{C}$ for B. raniceps). The level of thermal extremity of the areas was very low, ranging between $32 \%$ and $60 \%$ (Fig. 2, Table 1).

The monitored sites within each study area are located within vast open landscapes known as tropical or subtropical savannahs and are characterized by the predominance of grasslands, shrubs and open woodlands. Ponds and seasonally flooded fields therein serve as breeding habitats for the anuran species. In addition to the climatic criteria, the study areas were selected based on accessibility to private or restricted sites that facilitated fieldwork and reduced potential sources of human disturbance and damage to the equipment.

\section{Monitored populations}

A total of seven sites were monitored, four in FG and three in BR (Fig. 3), corresponding to 7 and 5 populations of $P$. paradoxa and B. raniceps, respectively. All populations were 
sympatric, except for two in FG, where B. raniceps was absent (FG1 and FG2; Fig. 3). The monitored populations in FG were located across two agricultural zones, locally known as

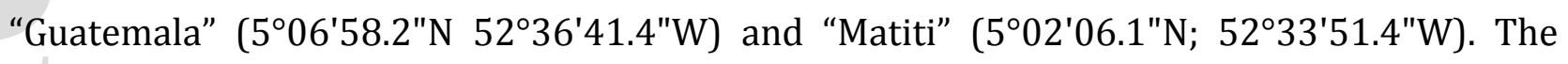
populations in BR were within the limits of the "Barranco Alto" farm (19³4'38.0"S; $\left.56^{\circ} 09^{\prime} 09.6 \mathrm{~W}\right)$. Water was present in the breeding habitats for the duration of the monitoring period. Surrounding areas included livestock farms and were composed of a mosaic of native grasslands and cultivated pastures, with woodland patches present up to 1 $\mathrm{km}$ from the monitored water bodies.

\section{Data collection}

Calling activity of the populations and weather conditions were monitored for 6-9 months in 2016-2017. The total monitoring period covered 295 consecutive days from 7/10/2016 to 29/07/2017 (Table 1) and encompassed an entire breeding season for both species, including the peak of calling activity and several weeks before and after the expected calling season.

Advertisement calls were recorded through passive acoustic monitoring using automated digital sound recorders (SM2 in FG and SM2, SM3 and SM4 in BR; Wildlife Acoustics, Inc.). One recorder was deployed at each breeding site. Each recorder was tied 1.5-2 $\mathrm{m}$ above ground to either a tree or a wooden stake located 1-15 $\mathrm{m}$ from the pond shore. All recorders were equipped with two omnidirectional condenser microphones (SMXII, Wildlife Acoustics, Inc.) and set to record sounds for 2 minutes every 20 minutes (i.e. 6 minutes per hour) from 1-2 hours before sunset until 0-1 hour after sunrise. This time period comprises the expected calling period of both species. The recording schedule was double the sampling effort shown to be adequate to record calling activity of temperate anurans (i.e. 3 minutes per hour; Shirose et al., 1997; and also see Alquezar \& Machado, 2015; Dorcas, Price, Walls \& Barichivich, 2009). The schedule was designed to increase both temporal resolution of sampling and species detectability in complex soundscapes, such as those found in tropical environments.

Audio settings were adjusted to record sounds in WAV stereo format at a sampling 
rate of $44.1 \mathrm{kHz}$ and 16-bit audio depth. Hourly measurements of precipitation (in mm), air temperature (in ${ }^{\circ} \mathrm{C}$ ) and relative air humidity (in \%) were obtained via the closest meteorological stations to the study areas, namely Mornand station in French Guiana (455'10.1"N; 52³1'38.3"W; approximately $20 \mathrm{~km}$ from the study area) and Aquidauana station in Brazil (20²8'31.5"S; 55²7'02.4"W; approximately $100 \mathrm{~km}$ from the study area).

\section{Sound analysis}

Sound analysis consisted of two main stages: (i) pre-processing for standardization of passive recordings (track selection, frequency filtering and amplitude normalization; see below) and (ii) detection and recognition of each species' signals through a semi-automated procedure. First, sound quality was manually checked from a random selection of recordings within each site for signal-to-noise ratio and microphone dysfunction in order to select the most suitable track. The sound recordings were then transformed from stereo to mono using the package "seewave" (Sueur et al., 2008) in R.3.2.5 (R Core Team, 2016). Second, to enhance species detection, recordings were standardized to increase overall quality and frequency resolution. A high-pass filter set at $500 \mathrm{~Hz}$ (roll-off of $36 \mathrm{~dB}$ ) and a low-pass filter set at 5,000 $\mathrm{Hz}$ (roll-off of $48 \mathrm{~dB}$ ) were applied to all recordings by batch processing in Audacity 2.1.2. (Audacity Team, 2014). The high-pass filter was chosen to reduce environmental noise and enhance signal-to-noise ratio while keeping the focal signals unaltered (Brumm, 2004; Penna, Pottstock \& Velasquez, 2005). The low-pass filter was chosen to remove other animal signals while preserving the highest spectral components of the advertisement call of the studied species (Lescure \& Marty, 2000). Finally, the sound amplitude in all recordings was normalized to maximum peak amplitude by batch processing in Audacity 2.1.2.

After the standardization procedure, audio files were processed to detect the calling activity of each species along the time series of passive recordings. We employed a semiautomated signal recognition procedure involving two steps (Llusia et al., 2013b). The first step consisted of searches based on spectrogram cross-correlation using a data template detector available in the XBAT R9 software (Figueroa \& Robbins, 2007). For this task, 
spectrograms of all recordings were created using a short-term Fourier transform (STFT) algorithm set to a window size of 512 points, an overlap of 96\% and a "Hann" tapering window. To build a signal detector for each species, species-specific call templates were selected from the whole dataset with an emphasis on representing overall variability in advertisement calls and acoustic conditions. Then, automated scans of the recorded time series were run using a correlation threshold of 50\% (i.e. the required correlation rate between any call template and a potential call event for it to be considered a positive detection) to control for false positives and false negatives. The second step involved manual audio-visual inspection of all spectrograms to validate each detected call event and to include new candidates, thus eliminating all false positives and significantly reducing false negatives.

Furthermore, a relative abundance index of the number of calling individuals was assigned to each 2-min recording. We used an adapted version of the Amphibian Calling Index (ACI) of the North American Amphibian Monitoring Program (NAAMP) protocol (Weir \& Mossman, 2005). In contrast with the original index that ranges from 0 to 3 , here the ACI values ranged from 0 to 5 , thus allowing a finer characterization of calling activity, and were defined as the following: 0 , absence of calling; 1 , seldom vocalizations from one or two isolated individuals; 2 , few vocalizations from countable individuals interspersed with noncalling periods; 3 , distinct calls from uncountable individuals and with only a few overlapping calls; 4, intermittent chorus, with discontinuous calls and some overlapping; and 5, full chorus, with continuous calls and constant overlapping. The first author (A.B.) assigned all ACI values to avoid potential deviations due to inter-observer effects (Pierce \& Hall, 2013).

\section{Data analysis}

A set of variables characterizing the calling activity of each species was obtained from the sound analysis of the passive audio recordings. First, presence $(\mathrm{ACI}>0)$ and absence $(\mathrm{ACI}=0)$ of calling activity was determined at a resolution of 20 minutes, which was then used to determine daily and seasonal activity patterns. Second, a maximum ACI value (hereafter 
maxACI) was calculated for each hour and then associated with corresponding hourly measurements of relative humidity and temperature. Thus, four variables per species were determined according to the intensity of calling activity: (i) calling humidity and (ii) calling temperature (i.e. relative humidity and temperature for hourly recordings with a maxACI between 1 and 3), and (iii) chorusing humidity and (iv) chorusing temperature (i.e. relative humidity and temperature for hourly recordings with a maxACI $>3$ ). Furthermore, (v) potential calling humidity and (vi) potential calling temperature were also estimated. These variables were defined as the relative humidity and temperature, recorded hourly, of the entire monitoring period at night (one hour before sunset to one hour before sunrise), i.e. the expected calling period of the species. Wilcoxon tests were used to check for regional differences in potential calling humidity and potential calling temperature between precipitation extremes. Daily averages of these variables were used in the analysis to prevent data autocorrelation associated with hourly-collected data (Llusia et al., 2013a).

To investigate the variation in climatic breadth of calling behaviour between species and populations, we used two generalized linear mixed models (GLMMs). The first model included calling humidity (\% of relative humidity) as the response variable, coded as a binomial response via a two-column matrix composed of the relative humidity at the time of calling (i.e. the percentage of saturated water vapour) and the percentage of unsaturated water vapour (i.e. 100 minus the relative humidity at the time of calling). A binomial error structure and the logit link function were applied to this model. The second GLMM included calling temperature $\left({ }^{\circ} \mathrm{C}\right)$ as the response variable, using a Gaussian error structure and the identity link function. The two models also included species (P. paradoxa and B. raniceps) and study area (FG and BR) as fixed factors, and sites (FG1-4 and BR1-3), recording day and recording hour as random factors.

Statistical analyses were performed using R 3.2.5 (R Core Team, 2016) and significance levels were set to a nominal type-I error of 5\%. The glmer and Imer functions in the R package Ime4 (Bates, Mächler, Bolker \& Walker, 2015) were used to build the two respective models. To keep the type-I error at 5\%, five random slopes (study area within recording day, study area within recording hour, species within population, species within recording day and species within recording hour) were included in each model (Barr, Levy, 
Scheepers \& Tily, 2013). For model inference, we performed likelihood-ratio tests through the anova function, which allows for a full-null model comparison. Null models comprised all predictor terms except for the fixed factors. To test for a potential interaction between species and areas, we compared models with and without this interaction term but found no significant differences and, thus, it was removed from the model. The effect of individual predictors on the response variable was also assessed through a full-null model comparison and a likelihood ratio test using the drop1 function.

Concerning test assumptions, the variance inflation factor was used to confirm absence of collinearity between fixed factors in all models, using the R gvif and vif functions. The first GLMM showed a dispersion parameter close to 1, revealing no over- or underdispersion. The residuals of the second GLMM were inspected by distribution probability plots that indicated no obvious deviations from the assumptions of normality and homoscedasticity. Confidence intervals of model coefficients were computed through 1,000 bootstrap iterations. Additionally, the daily and seasonal patterns of calling activity were compared graphically between species, study areas and populations.

\section{RESULTS}

\section{Calling activity}

A total of 76,629 2-min audio files (2,554 hours) was obtained from passive acoustic monitoring over 247 days of sampling in FG and 266 days in BR, with a mean of 3,649 hourly monitoring data per population (Table 1). Using a semi-automated procedure for signal recognition, we detected 9,488 calling events (i.e. number of hours with presence of calling activity from either of the studied species; Table 2), which were paired with local measurements of relative air humidity and temperature. The calling phenology differed between the study areas, and started 8 and 10 weeks in advance at the dry extremes for Pseudis paradoxa and Boana raniceps, respectively (S1). However, the calling activity of both species lasted similarly, with an average of 20 weeks for the season and 5 hours per night (Table 2). Among populations, the seasonal and daily duration of calling activity were highly 
variable, ranging from a total of 53 to 200 calling nights over the season and from 1 to 15 hours per day. When comparing the two areas located at the humidity extremes, the activity period only varied 5-10 nights and 0-2 hours per night between conspecific populations in FG and BR (Table 2).

\section{Weather conditions}

During the monitoring period, precipitation was as much as 4.5-fold higher in the humid (FG; $2,237 \mathrm{~mm}$ ) than in the dry extreme (BR, $494 \mathrm{~mm}$ ), and the potential calling humidity was significantly different between the two areas $\left(W=1,109.5, p<2.2 \cdot 10^{-16}\right.$; Fig. 4), which averaged $94 \%$ in $\mathrm{FG}$ and $74 \%$ in BR (Table 3). In contrast, the potential calling temperature was similar ( $W=35,220, p=0.136$; Fig. 4$)$, with an average of $24.7^{\circ} \mathrm{C}$ for both areas (Table 3). Overall, FG populations had narrower ranges of potential calling humidity and temperature than those in BR, where the weather conditions were highly variable across the breeding season (Table 2; Fig. 4).

\section{Calling humidity and calling temperature}

As shown by the full-null model comparison, the calling humidity of $P$. paradoxa and $B$. raniceps was significantly influenced by the model predictors (likelihood-ratio test: $\chi^{2}=42.1$, $\mathrm{df}=2$, $p$-value $=7.3 \cdot 10^{-10}$ ). The calling activity of conspecific populations of the two species located at the humidity extremes occurred at significantly different ranges of relative humidity $\left(\chi^{2}=37.9, \mathrm{df}=1, p\right.$-value $=7.5 \cdot 10^{-10}$; Table 3$)$, up to $21 \%$ higher in the humid $(\mathrm{FG})$ than the dry extreme (BR) (Table 3). Moreover, both species showed similar responses $\left(\chi^{2}=1.2, \mathrm{df}=1, p=0.26\right)$ and no obvious interaction between species and study areas was found $\left(\chi^{2}=3.4, \mathrm{df}=1, p=0.064\right)$. Over the study period, $P$. paradoxa and B. raniceps were recorded calling at relative humidities ranging from $75 \%$ to $100 \%$ in $\mathrm{FG}$ and from $31 \%$ to 97\% in BR (Table 2; Fig. 4). In contrast, calling temperature did not differ between humidity extremes or species (likelihood-ratio test: $\chi^{2}=0.7, \mathrm{df}=2, p$-value $=0.69$ ) and no interaction between these predictors was found $\left(\chi^{2}=1.2, \mathrm{df}=1, p\right.$-value $\left.=0.27\right)$. Calling activity occurred at temperatures ranging from $15^{\circ} \mathrm{C}$ to $34^{\circ} \mathrm{C}$ in $\mathrm{BR}$ and from $22^{\circ} \mathrm{C}$ to $30^{\circ} \mathrm{C}$ in $\mathrm{FG}$, and the mean 
calling temperature for both species and areas was around $25^{\circ} \mathrm{C}$ (Table 3). Moreover, the recorded climatic breadth of calling behaviour did not encompass the whole range of potential calling humidity and temperature observed at the study areas. Overall, calling activity was scarcely detected during the driest, hottest and coldest nights of the breeding season (Table 3; Fig. 4).

\section{Amphibian calling index}

According to the ACI, calling activity was not equally intense over the duration of the night and the breeding season (Fig. 5, S1), with marked differences in the number of calling individuals. However, the climatic breadth did not vary notably across ACI levels (Table 3). The mean and range of both relative humidity and temperature during chorusing activity (maxACI $>3$ ) were similar to those during calling activity $(1 \leq \operatorname{maxACI} \leq 3)$. Only the chorusing activity of $P$. paradoxa occurred under more restricted humidity conditions in the dry extreme (i.e. the minimum relative humidity was $12 \%$ higher than that at the humid extreme, Table 3).

The daily calling activity of all populations progressively increased after sunset, peaking just before midnight (Fig. 5). However, while the maximum abundance of calling individuals occurred at the same time in B. raniceps populations located at the humidity extremes, it occurred at a different time in those of $P$. paradoxa (i.e. 4 hours later at the dry extreme than at the humid one). As shown in Figure 5, despite these divergent temporal patterns, $P$. paradoxa did not perform calling behaviour under similar humidity conditions between the study areas. Thus, conspecific populations of both species exhibited a distinct calling humidity during the period of maximum abundance of calling individuals. In contrast, calling temperature at the peak of calling activity was similar across species and study areas (Fig. 5), in agreement with the general trend observed in overall calling humidity and calling temperature.

Regarding the breeding season, P. paradoxa started calling slightly after B. raniceps, and both species exhibited high levels of calling abundance even late in the season, particularly in the dry extreme (S1). However, the onset of calling activity was different 
between the two study areas: P. paradoxa and B. raniceps populations both started calling around mid-December in FG but approximately two months earlier in BR. Once the breeding season started, calling activity occurred mostly on a daily basis. However, the level of calling activity varied along the season, being higher at periods of intense precipitation. Toward the end of monitoring period, calling activity had greatly decreased in FG but was still occurring at high levels in BR (S1).

\section{DISCUSSION}

Passive acoustic monitoring of distant Neotropical populations under contrasting humidity conditions demonstrates that the studied frog species (Boana raniceps and Pseudis paradoxa) can perform calling behaviour across a broad range of relative humidity. In addition, a divergent pattern was observed between conspecific populations located at the humidity extremes of the species geographic distribution, indicating that calling humidity is not a fixed species trait and may potentially vary according to the precipitation regime experienced by populations. Although B. raniceps and P. paradoxa show distinct ecological and behavioural features, individuals of both species were reproductively active even under dry conditions, suggesting an extensive capacity in widespread Neotropical anurans to exhibit their sexual displays in different climatic environments.

The pattern of calling humidity observed here is congruent with the one found for calling temperature in populations of five temperate anurans located at the thermal extremes of their distribution (Llusia et al., 2013b). Both sets of studied species, i.e. temperate and widely distributed Neotropical anurans, showed a broad and populationspecific climatic breadth of calling behaviour. The capacity to maintain calling activity under variable weather conditions may reflect genetic or plastic responses associated with climatic tolerance (Angilletta, 2009; Duarte, Tejedo, Katzenberger, Marangoni, Baldo, Beltrán, Martí, Richter-Boix \& Gonzalez-Voyer, 2011), which might confer species some mechanisms to mitigate the effects of climate change. Moreover, the monitoring of calling behaviour and its abiotic determinants provides important eco-physiological information (Bovo et al., 2018) 
that can improve models forecasting climate change impacts on anurans (Araújo et al., 2006).

Divergent ranges of calling humidity across species distribution can be explained by either local adaptation or phenotypic plasticity (Corlett, 2011). On the one hand, local climatic conditions can generate selective pressures on species traits through adaptation, especially for species occupying habitats more vulnerable to climate changes, such as savannah biomes (Loarie et al., 2009). The observed differences in calling behaviour could reflect a process of disruptive selection, as the populations are geographically distant, favouring adaptation to local climatic regimes. Although evolutionary processes often require large time scales, rapid genetic adaptation driven by climate change has also been reported for specific phenotypic traits (Karell, Ahola, Karstinen, Valkama \& Brommer, 2011). Nevertheless, in the studied species, there is no clear support for these processes. Low genetic differentiation has been reported between the studied conspecific populations of $B$. raniceps (Fouquet et al., 2007; Jansen et al., 2011; Lyra et al., 2017) and most of the temperate species monitored so far (Llusia et al. 2013b), while subspecies can be recognized in both P. paradoxa (Aguiar et al., 2007; Garda \& Cannatella, 2007; Garda et al., 2010) and the temperate species Alytes obstetricans (Martínez-Solano, Gonçalves, Arntzen \& García-París, 2004).

On the other hand, phenotypic plasticity driven by environmental acclimation is a well-documented phenomenon that has been largely associated with temperature (Angilletta, 2009; Calosi, Bilton, Spicer \& Atfield, 2008; Gvoždík, 2012; Rome, Loughna \& Goldspink, 1984). The interannual variation in thermal breadth observed in the same populations of temperate anurans (Llusia et al. 2013b) supports acclimation as a potential mechanism that may lead to divergence in climatic breadth of calling behaviour. Yet, such responses associated with relative humidity remains mostly unexplored. Further investigations, such as common garden experiments (De Villemereuil, Gaggiotti, Mouterde, \& Till-Bottraud, 2016), are required to attribute the observed patterns to evolutionary or acclimation processes and to provide a better understanding of the potential role of relative humidity in the climatic tolerance of animal populations. 
Identifying the underlying mechanisms determining a species response to climate change is a daunting task (Merilä \& Hendry, 2014). Regardless of the specific mechanism, both selection and phenotypic plasticity might supply amphibians with key abilities under climate changes, although the potential of tolerance plasticity to buffer overheating risk in ectotherms has recently been questioned (Gunderson \& Stillman, 2015). The broad climatic breadth of calling behaviour in anurans might allow these animals to better cope with the effects of variations in humidity and temperature, especially during the performance of sexual displays.

Our findings were based on cross-sites comparisons across latitudinal gradient, a suitable approach to examine species responses to variation in climatic conditions (Weltzin et al. 2003). However, manipulative experiments are needed to fully assess the climatic tolerance of species. Innovative facilities based on mesocosms (Lawton et al., 1993) have recently been developed to recreate natural microhabitats under the control of abiotic factors (Gao, Jin, Llusia \& Li, 2015; Stewart et al., 2013). Such facilities can also be used in the experimental study of climatic tolerance of calling behaviour. Despite this, calling behaviour is a complex phenomenon, challenging to be reproduced under experimental settings, which hinders the determination of the limits of climatic tolerance, in comparison with physiological metrics as CTmax, and hence appropriated experimental designs must still to be developed.

Calling activity of both studied species was seldom recorded under the driest, coldest and hottest weather conditions during the breeding season. This partly corresponded to the onset of the season, when individuals emerge from estivation searching for suitable breeding sites, and the end, when they retreat to refuges (Brooke et al. 2000, Gao et al., 2015; Prado et al. 2005). Moreover, these low levels of calling activity may also reflect potential limits on the species climatic tolerance. Thermal limits associated with high-energy behaviours in adults, such as calling, are likely narrower than those associated with sub-lethal endpoints in larvae (Lutterschmidt \& Hutchison, 1997). Predictive models of climate change impacts on anurans should, therefore, consider to apply smaller ranges than the lethal thermal limits, otherwise, forecasts would presumably overestimate the response capacity of the species. In tadpole populations in Argentina, the critical thermal maximum (CTmax) was determined to 
be $42.25^{\circ} \mathrm{C}$ for $P$. paradoxa and $41.18^{\circ} \mathrm{C}$ for B. raniceps (Nava, 2009), while the maximum calling temperature recorded for the same species in our study was $33.9^{\circ} \mathrm{C}$ and $32.7^{\circ} \mathrm{C}$, respectively. The calling temperatures found here were estimated from populations subjected to average thermal conditions; therefore, we hypothesize that populations at the thermal extremes of the studied species' ranges would have higher calling temperatures.

The variation in climatic conditions that species experience in their habitats is expected to influence their eco-physiological tolerance to climate change (Ghalambor, Huey, Martin, Tewksbury \& Wang, 2006; Janzen, 1967). Thus, tropical ectotherms are likely more sensitive to temperature changes than temperate-zone species (Bonetti \& Wiens, 2014; Deutsch et al., 2008; Duarte et al., 2011; Sunday, Bates \& Dulvy, 2011). Although variation in thermal tolerance at different latitudes may be negligible, the degree of seasonality has an effect on the plasticity of thermal responses (Gunderson \& Stillman, 2015). Climate change is expected to drive significant shifts in the magnitude and concentration of seasonal rainfall in the tropics (Feng, Porporato, \& Rodriguez-Iturbe, 2013). Additionally, local abiotic factors play a major role in restraining the warming tolerances of tropical amphibians, and behavioural adjustments associated with habitat-use can help certain ectotherms cope with increasing climatic variation (Duarte et al., 2011).

Our thorough analysis of the temporal patterns of calling activity between species and study areas revealed particular aspects of the climatic breadth of calling behaviour. Conspecific populations of $P$. paradoxa showed different daily patterns of calling activity at the humidity extremes, suggesting that the temporal shift in peak calling activity in this species is not driven by hydric conditions, as relative humidity ranges differed between the distant regions at the daily activity peaks. Multiple factors can influence the daily pattern of calling activity in anurans, such as weather condition, competitive exclusion, social facilitation and predator pressure (Brooke et al., 2000; Llusia et al., 2013a; Oseen \& Wassersug, 2002). The period of breeding season is closely linked to seasonal precipitation, particularly at the humid extremes, and the period observed in our study is consistent with those observed in previous studies of the same species (Prado et al., 2005). Seasonal patterns of anuran calling activity are strongly related to rainfall, especially in the tropics, which have heavy rainy seasons (Donnelly \& Guyer, 1994; Ulloa, Aubin, Llusia, Courtois, 
Fouquet, Gaucher, Pavoine \& Sueur, 2019). In temperate regions, these patterns have mostly been linked to the joint effect of temperature and rainfall (Caldwell, 1987; Llusia et al., 2013a; Oseen \& Wassersug, 2002). However, seasonal patterns of calling activity may be less closely related to rainfall at dry extremes given that they are located at higher latitudes and are characterized by a subtropical climate (i.e. a different amplitude range of temperature and drier conditions).

Climate change impacts on habitats may also affect species persistence, directly or in combination with other identified drivers of amphibian population decline (Carey \& Alexander, 2003; Hof et al., 2011). Changes in rainfall volume and seasonality greatly alter the availability of breeding sites and the hydroperiod of amphibians, thus compromising reproduction, larval development and population survival (Burrowes et al., 2004; Stewart, 1995). Habitat changes or loss due to precipitation extremes that produce torrents can also lead to an increase in amphibian mortality at all life stages (Bickford, Howard, Ng \& Sheridan, 2010). The tropical savannahs inhabited by many amphibian species are also particularly threatened at both global and local scales (Overbeck et al., 2015; Roque et al., 2016; Silva \& Bates, 2002). In French Guiana, where savannahs represent only $0.3 \%$ of the territory, savannah habitats are jeopardized by land-use transformation and urbanization. Population decline has been the trend in both of the studied species over the last 10 years, and a recent regional red list assessment has classed $B$. raniceps as endangered and $P$. paradoxa as near threatened (UICN France et al., 2017). In the Pantanal, the continuous removal of native vegetation in the uplands is so severe that it has led to changes in the population dynamics and persistence of species in the lowlands (Roque et al., 2016).

As shown here and in previous studies (Krause \& Farina, 2016; Llusia et al., 2013b; Sueur et al., 2019), automated acoustic monitoring techniques (Sugai et al., 2019) can provide important information on species behaviour under different climatic conditions, thus assisting climate change research. With these new techniques, the thermal breadth of calling activity can also be further investigated and provide a complementary view on the response capacity of anuran amphibians to climate change. For instance, monitoring the sexual displays of populations that experience similar precipitation regimes but contrasting thermal conditions will shed light on the extent to which certain tropical species are 
vulnerable to global warming. Automated acoustic monitoring can also be used to compare the climatic breadth of calling behaviour between narrowly distributed species and widely distributed species. Other aspects of the acoustic communication systems of the studied species, such as variations in call parameters or hearing sensitivity, may also be affected by climatic conditions and should be further explored. Since temporal features of calls (e.g. call rate, call duration or duty cycle) are temperature-dependent (Narins et al., 2007) as well as key selected traits in female choice (Gerhardt \& Huber, 2002), it is expected that climate change cause indirect effects on physiology of calling males, calling performance and sexual selection in anurans, among other consequences. Finally, future experimental studies should focus on determining the climatic tolerance of calling behaviour in anurans and clarifying the underlying mechanisms driving species responses.

\section{ACKNOWLEDGEMENTS}

We thank the staff at Barranco Alto Farm (Brazil) and the staff and students at Matiti High School (French Guiana), particularly Headmistress Mme Arbellot-De-Vacqueur and M. Delfoe, for their involvement and for hosting our project; Antoine Fouquet for providing useful information on the population genetics and taxonomic status of the studied species; Phillipe Gaucher for his expertise in anuran species acoustic detection; Camille Desjonquères and Melinda Modrell for providing very useful comments on the manuscript; Farid DahdouhGuebas and Josiane Pauchont for help with the project paperwork; and João Vitor Andriola and Andres Rymel Acosta Galvis for their personal permission to reproduce the pictures of B. raniceps and P. paradoxa, respectively. LSMS acknowledges M.C. Ribeiro for providing some of the audio recorders, grants \#2015/25316-6 and \#2017/15772-0, São Paulo Research Foundation (FAPESP); Programa Nacional de Cooperação Acadêmica (Procad) 07/2013, project 88881.068425/2014-01; Programa de Apoio à Pós-Graduação (PROAP) 817737/2015 from the Coordenação de Aperfeiçoamento de Pessoal de Nível Superior (CAPES); and a Small Grant from The Rufford Foundation. DLL acknowledges postdoctoral grants by the European Commission (EAVESTROP-661408, Global Marie S. Curie fellowship, program H2020, EU) and the Comunidad de Madrid (2016-T2/AMB-1722, Atracción de Talento Investigador, Spain). This study was funded by the Labex CEBA (ANR- 
10-LABX-25-01, Center for the study of biodiversity in Amazonia), as part of the project CALL (Estimating the effects of climate changes on calling behaviour of tropical amphibians), coordinated by EC and DLL, and by the Ministerio de Economía, Industria y Competitividad (CGL2017-88764-R, MINECO/AEI/FEDER, Spain), as part of the project SoundClim (The sound of biogeography: Predicting climate change impacts on amphibians based on new acoustic monitoring technology), coordinated by DLL.

\section{DATA AVAILABILITY STATEMENT}

The dataset that supports the findings of this study is archived in the Universidad Autónoma de Madrid and available from the corresponding author upon reasonable request. A subset of this database is available from e-cienciaDatos in <https://doi.org/10.21950/LHESKW> (Bonnefond et al. 2020).

\section{REFERENCES}

Almeida-Gomes, M., Van Sluys, M., \& Duarte Rocha, C. F. (2007). Calling activity of Crossodactylus gaudichaudii (Anura: Hylodidae) in an Atlantic Rainforest area at Ilha Grande, Rio de Janeiro, Brasil. Belgian Journal of Zoology, 137, 203.

Alquezar, R. D., Machado, R. B. (2015). Comparisons between autonomous acoustic recordings and avian point counts in open woodland savanna. The Wilson Journal of Ornithology 127, 712723.

Angilletta, M. J. (2009). Thermal Adaptation: a theoretical and empirical synthesis, Oxford University Press.

Angulo, A., \& Baldo, D. (2010). Pseudis paradoxa. The IUCN Red List of Threatened Species 2010: $<$ http://dx.doi.org/10.2305/IUCN.UK.2010-2.RLTS.T55904A11385563.en>. Downloaded on 28 March 2017.

Araújo, M. B., Thuiller, W., \& Pearson, R. G. (2006). Climate warming and the decline of amphibians and reptiles in Europe. Journal of Biogeography, 33, 1712-1728.

Assine, M. L. (2005). River avulsions on the Taquari megafan, Pantanal wetland, Brazil. Geomorphology, 70, 357-371.

This article is protected by copyright. All rights reserved 
Audacity Team (2014). Audacity(R): Free Audio Editor and Recorder. Version 2.1.2 https://audacityteam.org/

Barr, D. J., Levy, R., Scheepers, C., \& Tily, H. J. (2013). Random effects structure for confirmatory hypothesis testing: Keep it maximal. Journal of Memory and Language, 68, 255-278.

Bates, D., Mächler, M., Bolker, B., \& Walker, S. (2015). Fitting linear mixed-effects models using lme4. 2015, 67, 48.

Beebee, T. J. C., \& Griffiths, R. A. (2005). The amphibian decline crisis: A watershed for conservation biology? Biological Conservation, 125, 271-285.

Bickford, D., Howard, S. D., Ng, D. J. J., \& Sheridan, J. A. (2010). Impacts of climate change on the amphibians and reptiles of Southeast Asia. Biodiversity and Conservation, 19, 1043-1062.

Bonetti, M. F., \& Wiens, J. J. (2014). Evolution of climatic niche specialization: a phylogenetic analysis in amphibians. Proceedings of the Royal Society B: Biological Sciences, 281, 20133229.

Bosch, J., Carrascal, L. M., Duran, L., Walker, S. \& Fisher, M. C. (2006). Climate change and outbreaks of amphibian chytridiomycosis in a montane area of Central Spain; is there a link? Proceedings of the Royal Society B: Biological Sciences, 274, 253-260.

Bosch, J., De La Riva, I., \& Márquez, R. (1996). The calling behaviour of Lysapsus limellus and Pseudis paradoxa (Amphibia: Anura: Pseudidae). Folia Zoologica, 45, 49-55.

Bovo, R., Navas, C., Tejedo, M., Valença, S., \& Gouveia, S. (2018). Ecophysiology of amphibians: information for best mechanistic models. Diversity, 10, 118.

Brooke, P. N., Alford, R. A., \& Schwarzkopf, L. (2000). Environmental and social factors influence chorusing behaviour in a tropical frog: examining various temporal and spatial scales. Behavioral Ecology and Sociobiology, 49, 79-87.

Brumm, H. (2004). The impact of environmental noise on song amplitude in a territorial bird. Journal of Animal Ecology, 73, 434-440.

Burrowes, P. A., Joglar, R. L., \& Green, D. E. (2004). Potential causes for amphibian declines in Puerto Rico. Herpetologica, 60, 141-154, 114.

Caldwell, J. P. (1987). Demography and life history of two species of chorus frogs (Anura: Hylidae) in South Carolina. Copeia, 1987, 114-127.

Calosi, P., Bilton, D. T., Spicer, J. I., \& Atfield, A. (2008). Thermal tolerance and geographical range size in the Agabus brunneus group of European diving beetles (Coleoptera: Dytiscidae). Journal of Biogeography, 35, 295-305.

Carey, C., \& Alexander, M. A. (2003). Climate change and amphibian declines: is there a link? Diversity and Distributions, 9, 111-121.

Coffel, E. D., Horton, R. M., \& Sherbinin, A. (2018). Temperature and humidity based projections of a 
rapid rise in global heat stress exposure during the 21st century. Environmental Research Letters, 13, 014001.

Collins, J. P., \& Storfer, A. (2003). Global amphibian declines: sorting the hypotheses. Diversity and Distributions, 9, 89-98.

Corlett, R. T. (2011). Impacts of warming on tropical lowland rainforests. Trends in Ecology \& Evolution, 26, 606-613.

Cowley, E., \& Siriwardena, G. M. (2005). Long-term variation in survival rates of Sand Martins Riparia riparia: dependence on breeding and wintering ground weather, age and sex, and their population consequences. Bird Study, 52, 237-251.

Crump, M. L. (2015). Anuran reproductive modes: evolving perspectives. Journal of Herpetology, 49, $1-16$.

D'Amen, M. \& Bombi, P. (2009). Global warming and biodiversity: Evidence of climate-linked amphibian declines in Italy. Biological Conservation, 142, 3060-3067.

Davidson, E. A., De Araújo, A. C., Artaxo, P., Balch, J. K., Brown, I. F., C. Bustamante, M. M., ... Wofsy, S. C. (2012). The Amazon basin in transition. Nature, 481, 321.

Deutsch, C. A., Tewksbury, J. J., Huey, R. B., Sheldon, K. S., Ghalambor, C. K., Haak, D. C., \& Martin, P. R. (2008). Impacts of climate warming on terrestrial ectotherms across latitude. Proceedings of the National Academy of Sciences, 105, 6668-6672.

Donnelly, M. A., \& Guyer, C. (1994). Patterns of reproduction and habitat use in an assemblage of Neotropical hylid frogs. Oecologia, 98, 291-302.

Dorcas, M. E., Price, S. J., Walls, S. C., Barichivich, W. J. (2009). Auditory monitoring of anuran population. In Conservation and ecology in amphibians: 281-298. Dodd, C. K. (Ed.). Oxford, UK: Oxford University Press.

Duarte, H., Tejedo, M., Katzenberger, M., Marangoni, F., Baldo, D., Beltrán, J.F., Martí, D.A., Richter-Boix, A. and Gonzalez-Voyer, A. (2012). Can amphibians take the heat? Vulnerability to climate warming in subtropical and temperate larval amphibian communities. Global Change Biology, 18, 412-421.

Dubois, A. 2017. The nomenclatural status of Hysaplesia, Hylaplesia, Dendrobates and related nomina (Amphibia, Anura), with general comments on zoological nomenclature and its governance, as well as on taxonomic databases and websites. Bionomina 11, 1-48

Dunn, P. O., \& Møller, A. P. (2014). Changes in breeding phenology and population size of birds. Journal of Animal Ecology, 83, 729-739.

Emerson, S. B. (1988). The giant tadpole of Pseudis paradoxa. Biological Journal of the Linnean Society, 34, 93-104. 
Feder, M. E., \& Burggren, W. W. (1992). Environmental physiology of the amphibians, Chicago, USA, University of Chicago Press.

Feng, X., Porporato, A., \& Rodriguez-Iturbe I. (2013). Changes in rainfall seasonality in the tropics. Nature Climate Change, 3, 811-815.

Fick, S.E. and R.J. Hijmans, 2017. Worldclim 2: New 1-km spatial resolution climate surfaces for global land areas. International Journal of Climatology, 37, 4302-4315.

Figueroa, H., \& Robbins, M. (2007). XBAT: An open-source extensible platform for bioacoustic research and monitoring. In: Proceedings of the International Expert Meeting on IT-based Detection of Bioacoustical Patterns.

Frost, D.R. (2016). Amphibian Species of the World: An Online Reference. Version 6.0 Electronic Database http://research.amnh.org/herpetology/amphibia/index.html. Downloaded on 6 November 2016. American Museum of Natural History, New York, USA.

Ghalambor, C. K., Huey, R. B., Martin, P. R., Tewksbury, J. J., \& Wang, G. (2006). Are mountain passes higher in the tropics? Janzen's hypothesis revisited. Integrative and comparative biology, 46, 5-17.

Gao, X., Jin, C., Llusia, D., \& Li, Y. (2015). Temperature-induced shifts in hibernation behavior in experimental amphibian populations. Scientific Reports, 5, 11580.

Gerhard, H. C., \& Huber, F. (2002). Acoustic communication in insects and anurans: common problems and diverse solutions Chicago, IL, Chicago University Press.

Giam, X. (2017) Global biodiversity loss from tropical deforestation. Proceedings of the National Academy of Sciences of the Unites States of America, 114, 5775-5777.

Gilman, S. E., Urban, M. C., Tewksbury, J., Gilchrist, G. W., \& Holt, R. D. (2010). A framework for community interactions under climate change. Trends in Ecology \& Evolution, 25, 325-331.

Grant, R., Halliday, T., \& Chadwick, E. (2013). Amphibians' response to the lunar synodic cycle-a review of current knowledge, recommendations, and implications for conservation. Behavioral Ecology, 24, 53-62.

Guimarães, L. D. A., \& Bastos, R. P. (2003). Vocalizações e interações acústicas em Hyla raniceps (Anura, Hylidae) durante a atividade reprodutiva. Iheringia. Série Zoologia, 93, 149-158.

Gunderson, A. R., \& Stillman, J. H. (2015). Plasticity in thermal tolerance has limited potential to buffer ectotherms from global warming. Proceedings of the Royal Society B: Biological Sciences, 282, 20150401.

Gvoždík, L. (2012). Plasticity of preferred body temperatures as means of coping with climate change? Biology Letters, 8, 262-265.

This article is protected by copyright. All rights reserved 
Haddad CFB, Toledo LF, Prado CPA, Loebmann D, Gasparini JL, Sazima I. (2013) Guia dos anfíbios da Mata Atlântica: diversidade e biologia. São Paulo: Anolis Books Editora.

Haddad, C. F. B., \& Prado, C. P. A. (2005). Reproductive modes in frogs and their unexpected diversity in the Atlantic Forest of Brazil. Bioscience, 55, 207-2017.

Hatano, F. H., Rocha, C. F. D., \& Sluys, M. V. (2002). Environmental factors affecting calling activity of a tropical diurnal frog (Hylodes phyllodes: Leptodactylidae). Journal of Herpetology, 36, 314318.

Hecnar, S. J. (1997). Amphibian pond communities in southwestern Ontario. Amphibians in decline: Canadian studies of a global problem. (ed. by D.M. Green). Herpetological Conservation, 1, 115.

Henzi, S. P., Dyson, M. L., Piper, S. E., Passmore, N. E. \& Bishop, P. (1995). Chorus attendance by male and female painted reed frogs (Hyperolius marmoratus): environmental factors and selection pressures. Functional Ecology, 9, 485-491.

Hickling, R., Roy, D. B., Hill, J. K., Fox, R., \& Thomas, C. D. (2006). The distributions of a wide range of taxonomic groups are expanding polewards. Global Change Biology, 12, 450-455.

Hof, C., Araujo, M. B., Jetz, W., \& Rahbek, C. (2011). Additive threats from pathogens, climate and landuse change for global amphibian diversity. Nature, 480, 516-519.

Hoffmann, M., Hilton-Taylor, C., Angulo, A., Böhm, M., Brooks, T. M., Butchart, S. H., ... \& Darwall, W. R. (2010). The impact of conservation on the status of the world's vertebrates. Science, 330, 1503-1509.

Huey, R. B., Kearney, M. R., Krockenberger, A., Holtum, J. A., Jess, M., \& Williams, S. E. (2012). Predicting organismal vulnerability to climate warming: roles of behaviour, physiology and adaptation. Philosophical Transactions of the Royal Society B: Biological Sciences, 367, 16651679.

Huntington, T. G. (2006). Evidence for intensification of the global water cycle: Review and synthesis. Journal of Hydrology, 319, 83-95.

IPCC (2007). Summary for Policymakers. In: Climate change 2007: The physical science basis. contribution of working group I to the fourth assessment report of the intergovernmental panel on climate change. (eds Solomon S, Qin D, Manning M, Chen Z, Marquis M, Averyt KB, Tignor M, Miller HL). Cambridge, United Kingdom and New York, NY, USA, Cambridge University Press.

IPCC (2013). Summary for policymakers. In: Climate change 2013: the physical science basis: working group I contribution to the fifth assessment report of the intergovernmental panel on climate 
change. (eds Stocker Tf, Qin D, Plattner G-K, Tignor M, Allen Sk, Boschung J, Nauels A, Xia Y, Bex V, Pm M). Cambridge, UK and New York, NY, USA, Cambridge University Press.

IUCN (International Union for Conservation of Nature), Conservation \& Nature and NatureServe (2008a). Hypsiboas raniceps. In: IUCN 2012. IUCN Red List of Threatened Species. Version 2012.1. <http://www.iucnredlist.org>. Downloaded on 28 November 2016.

IUCN (International Union for Conservation of Nature), Conservation \& Nature and NatureServe (2008b). Pseudis paradoxa. In: IUCN 2012. IUCN Red List of Threatened Species. Version 2012.1. <http://www.iucnredlist.org>. Downloaded on 12 December 2016.

Jansen, M., Schulze, A., Werding, L., \& Streit, B. (2009). Effects of extreme drought in the dry season on an anuran community in the Bolivian Chiquitano region. Salamandra, 45, 233-238.

Janzen, D. H. (1967). Why mountain passes are higher in the tropics. The American Naturalist, 101, 233-249.

Karell, P., Ahola, K., Karstinen, T., Valkama, J., \& Brommer, J. E. (2011). Climate change drives microevolution in a wild bird. Nature communications, 2, 208-208.

Köhler, J., Jansen M., Rodríguez A., Kok P. J. R., Toledo L. F., Emmrich M., ... Vences, M. (2017). The use of bioacoustics in anuran taxonomy: theory, terminology, methods and recommendations for best practice. Zootaxa, 4251, 1-124.

Krause, B., \& Farina, A. (2016). Using ecoacoustic methods to survey the impacts of climate change on biodiversity. Biological Conservation, 195, 245-254.

La Marca, E., Azevedo-Ramos, C., Silvano, D., Scott, N., Aquino, L., \& Faivovich, J. (2004). Hypsiboas raniceps. The IUCN Red List of Threatened Species 2004: <http://dx.doi.org/10.2305/IUCN.UK.2004.RLTS.T55622A11341908.en> Downloaded on 25 April 2017.

Lawton, J. H., Naeem, S., Woodfin, R. M., Brown, V. K., Gange, A., Godfray, H. J. C., . . Young, S. (1993). The Ecotron: a controlled environmental facility for the investigation of population and ecosystem processes. Philosophical Transactions of the Royal Society of London. Series B: Biological Sciences, 341, 181-194.

Lescure, J., \& Marty, C. (2000). Atlas des amphibiens de Guyane. Patrimoines Naturels, (45). Publications Scientifiques du M.N.H.N, Paris, France.

Li, Y. Cohen, J. M. \& Rohr, J. R. (2013). Review and synthesis of the effects of climate change on amphibians. Integrative Zoology, 8(2), pp.145-161 
Lips, K. R., Diffendorfer, J., Mendelson, J. R., Iii, \& Sears, M. W. (2008). Riding the wave: reconciling the roles of disease and climate change in amphibian declines. PLoS Biology, 6, e72.

Llusia, D., Márquez, R., Beltrán, J. F., Benítez, M., \& Amaral, J. P. (2013b). Calling behaviour under climate change: geographical and seasonal variation of calling temperatures in ectotherms. Global Change Biology, 19, 2655-2674.

Llusia, D., Márquez, R., Beltrán, J. F., Moreira, C., \& Amaral, J. P. (2013a). Environmental and social determinants of anuran lekking behavior: intraspecific variation in populations at thermal extremes. Behavioral Ecology and Sociobiology, 67, 493-511.

Loarie, S. R., Duffy, P. B., Hamilton, H., Asner, G. P., Field, C. B., \& Ackerly, D. D. (2009). The velocity of climate change. Nature, 462, 1052.

Lutterschmidt, W. I., \& Hutchison, V. H. (1997). The critical thermal maximum: history and critique. Canadian Journal of Zoology, 75, 1561-1574.

MacLaren, A. R., McCracen, S. F., \& Forstner, M. R. J. (2018). Automated monitoring techniques reveal new proximate cues of Houston toad chorusing behavior. Herpetological Review, 49, 622-626.

Márquez, R., De La Riva, I., \& Bosch, J. (1993). Advertisement Calls of Bolivian Species of Hyla (Amphibia, Anura, Hylidae). Biotropica, 25, 426-443.

Martínez-Solano, I., Gonçalves, H.A., Arntzen, J.W., García-París M. (2004) Phylogenetic relationships and biogeography of midwife toads (Discoglossidae: Alytes). Journal of Biogeography, 31, 603-618.

Mcdiarmid, R. (1994). Amphibian diversity and natural history: An overview. In: Measuring and monitoring biological diversity: standard methods for amphibians. (eds Heyer W, Donnelly M, Mcdiarmid R, Hayek L, Foster M). Washington (DC), Smithsonian Institution Press.

Mcmenamin, S. K., \& Hadly, E. A. (2010). Developmental dynamics of Ambystoma tigrinum in a changing landscape. BMC Ecology, 10, 10.

Merilä, J., \& Hendry, A. P. (2014). Climate change, adaptation, and phenotypic plasticity: the problem and the evidence. Evolutionary Applications, 7, 1-14.

Murphy, C. G. (2003). The cause of correlations between nightly numbers of male and female barking treefrogs (Hyla gratiosa) attending choruses. Behavioral Ecology, 14, 274-281.

Narins, P. M., Feng, A. S., Fay, R. R., \& Popper, A. N. (2007). Hearing and sound communication in amphibians, New York, NY, Springer.

Nava, M. J. K. B. (2009). Thermal tolerance and sensitivity of amphibian larvae from Paleartic and Neotropical communities (Doctoral dissertation).

New, M., Todd, M., Hulme, M., \& Jones, P. (2001). Precipitation measurements and trends in the twentieth century. International Journal of Climatology, 21, 1889-1922.

This article is protected by copyright. All rights reserved 
O’Hanlon, S. J., Rieux, A., Farrer, R. A., Rosa, G. M., Waldman, B., Bataille, A., . . Fisher, M. C. (2018). Recent Asian origin of chytrid fungi causing global amphibian declines. Science, 360, 621-627.

Ockendon, N., Baker, D. J., Carr, J. A., White, E. C., Almond, R. E. A., Amano, T., . . Pearce-Higgins, J. W. (2014). Mechanisms underpinning climatic impacts on natural populations: altered species interactions are more important than direct effects. Global Change Biology, 20, 2221-2229.

Oseen, K., \& Wassersug, R. (2002). Environmental factors influencing calling in sympatric anurans. Oecologia, 133, 616-625.

Overbeck, G. E., Vélez-Martin, E., Scarano, F. R., Lewinsohn, T. M., Fonseca, C. R., Meyer, S. T., . . Loyola, R. (2015). Conservation in Brazil needs to include non-forest ecosystems. Diversity and Distributions, 21, 1455-1460.

Peel, M. C., Finlayson, B. L. \& McMahon, T. A. (2007). Updated world map of the Köppen-Geiger climate classification. Hydrology and earth system sciences discussions, 4, 439-473.

Penna, M., Pottstock, H., \& Velasquez, N. (2005). Effect of natural and synthetic noise on evoked vocal responses in a frog of the temperate austral forest. Animal Behaviour, 70, 639-651.

Pierce, B. A., \& Hall, A. S. (2013). Call latency as a measure of calling intensity in anuran auditory surveys. Herpetological Conservation and Biology, 8, 199-206.

Prado, C., \& Haddad, C. F. (2005). Size-fecundity relationships and reproductive investment in female frogs in the Pantanal, South-Western Brazil. The Herpetological Journal, 15, 181-189.

Prado, C., Uetanabaro, M., \& Haddad, C. (2005). Breeding activity patterns, reproductive modes, and habitat use by anurans (Amphibia) in a seasonal environment in the Pantanal, Brazil. Amphibia-Reptilia, 26, 211-221.

R Core Team (2016). R: A language and environment for statistical computing. R Foundation for Statistical Computing, Vienna, Austria.

Río, S. D., Herrero, L., Fraile, R., \& Penas, A. (2011). Spatial distribution of recent rainfall trends in Spain (1961-2006). International Journal of Climatology, 31, 656-667.

Rohr, J. R., Raffel, T. R., Romansic, J. M., Mccallum, H., \& Hudson, P. J. (2008). Evaluating the links between climate, disease spread, and amphibian declines. Proceedings of the National Academy of Sciences, 105, 17436-17441.

Rome, L. C., Loughna, P. T. and Goldspink, G. (1985). Temperature acclimation: improved sustained swimming performance in carp at low temperatures. Science, 228, 194-196.

Roque, F. O., Ochoa-Quintero, J., Ribeiro, D. B., Sugai, L. S. M., Costa-Pereira, R., Lourival, R., \& Bino, G. (2016). Upland habitat loss as a threat to Pantanal wetlands. Conservation Biology, 30, 11311134.

Santana, D.J., Magalhaes, F.M., São-Pedro, V.A., Mângia, S., Amado, T.F. \& Garda, A.A. (2016) Calls and 
tadpoles of the species of Pseudis (Anura, Hylidae, Pseudae). Herpetological Journal, 26, 139148.

Scheele, B. C., Driscoll, D. A., Fischer, J., \& Hunter, D. A. (2012). Decline of an endangered amphibian during an extreme climatic event. Ecosphere, 3, art101.

Shirose, L. J., Bishop, C. A., Green, D. M., Cameron, J. M., Brooks, R. J., \& Natalie, J. H. (1997). Validation tests of an amphibian call count survey technique in Ontario, Canada. Herpetologica, 53, 312320.

Shrader, A. M., Pimm, S. L., \& Van Aarde, R. J. (2010). Elephant survival, rainfall and the confounding effects of water provision and fences. Biodiversity and Conservation, 19, 2235-2245.

Silva, J. M. C. D., \& Bates, J. M. (2002). Biogeographic patterns and conservation in the South American Cerrado: a tropical savannah hotspot. Bioscience, 52, 225-234.

Sinervo, B., Méndez-De-La-Cruz, F., Miles, D. B., Heulin, B., Bastiaans, E., Villagrán-Santa Cruz, M., . . . Sites, J. W. (2010). Erosion of lizard diversity by climate change and altered thermal niches. Science, 328, 894-899.

Smith, T. M., Yin, X., \& Gruber, A. (2006). Variations in annual global precipitation (1979-2004), based on the Global Precipitation Climatology Project 2.5 analysis. Geophysical Research Letters, 33, L06705.

Steelman, C. K., \& Dorcas, M. E. (2010). Anuran calling survey optimization: Developing and testing predictive models of anuran calling activity. Journal of Herpetology, 44, 61-68.

Stewart, M. M. (1995). Climate driven population fluctuations in rain forest frogs. Journal of Herpetology, 29, 437-446.

Stewart, R. I. A., Dossena, M., Bohan, D. A., Jeppesen, E., Kordas, R. L., Ledger, M. E., .. Woodward, G. (2013) Chapter Two - Mesocosm experiments as a tool for ecological climate-change research. Advances in Ecological Research, 48, 71-181.

Strassburg, B. B. N., Brooks, T., Feltran-Barbieri, R., Iribarrem, A., Crouzeilles, R., Loyola, R., Latawiec, A. E., Oliveira Filho, F. J. B., Scaramuzza, C. A. de M., Scarano, F. R., Soares-Filho, B., \& Balmford, A. (2017). Moment of truth for the Cerrado hotspot. Nature Ecology and Evolution, 1, 0099.

Sueur J., Aubin T., \& Simonis C. (2008). Seewave: a free modular tool for sound analysis and synthesis. Bioacoustics, 18, 213-226.

Sueur, J., \& Farina, A. (2015). Ecoacoustics: the ecological investigation and interpretation of environmental sound. Biosemiotics, 8, 493-502

Sueur, J., Krause, B., \& Farina, A. (2019). Climate Change Is Breaking Earth's Beat. Trends in Ecology \& Evolution, 34, 971-973.

This article is protected by copyright. All rights reserved 
Sugai, L. S. M., Silva, T. S. F., Ribeiro, J. W., Jr, \& Llusia, D. (2019). Terrestrial passive acoustic monitoring: review and perspectives. Bioscience, 69, 15-25.

Sunday, J. M., Bates, A. E., \& Dulvy, N. K. (2011). Global analysis of thermal tolerance and latitude in ectotherms. Proceedings of the Royal Society B: Biological Sciences, 278, 1823-1830.

Tárano, Z. (2010). Advertisement calls and calling habits of frogs from a flooded savannah of Venezuela. South American Journal of Herpetology, 5, 221-240.

Thackeray, S. J., Sparks, T. H., Frederiksen, M., Burthe, S., Bacon, P. J., Bell, J. R., . . Wanless, S. (2010). Trophic level asynchrony in rates of phenological change for marine, freshwater and terrestrial environments. Global Change Biology, 16, 3304-3313.

UICN France, MNHN, GEPOG, Kwata, Biotope, Hydreco, \& OSL (2017). La Liste rouge des espèces menacées en France - Chapitres de la Faune vertébrée de Guyane. Paris, France.

Ulloa, J. S., Aubin, T., Llusia, D., Courtois, E. A., Fouquet, A., Gaucher, P., Pavoine, S. \& Sueur, J. (2019). Explosive breeding in tropical anurans: environmental triggers, community composition and acoustic structure. BCM Ecology, 0, 000-000.

De Villemereuil, P., Gaggiotti, O. E., Mouterde, M., \& Till-Bottraud, I. (2016). Common garden experiments in the genomic era: new perspectives and opportunities. Heredity, 116, 249254.

Wake, D. B. \& Vredenburg, V.T. (2008). Are we in the midst of the sixth mass extinction? A view from the world of amphibians. Proceedings of the National Academy of Sciences, 105, 11466-11473.

Weir, L. A., \& Mossman, M. J. (2005) North American amphibian monitoring program (NAAMP). In: Amphibian declines: the conservation status of United States species (ed Lanoo M). Berkeley, University of California Press.

Wells, K. D., \& Schwartz, J. J. (2007) The behavioral ecology of anuran communication. In: Hearing and Sound Communication in Amphibians. (eds Narins PM, Feng AS, Fay RR, Popper AN). New York, NY, Springer New York.

Weltzin, J. F., Loik, M. E., Schwinning, S., Williams, D. G., Fay, P. A., Haddad, B. M., ... \& Pockman, W. T. (2003). Assessing the response of terrestrial ecosystems to potential changes in precipitation. Bioscience, 53(10), 941-952.

Wilson, R. J., Gutiérrez, D., Gutiérrez, J., Martínez, D., Agudo, R. and Monserrat, V. J., (2005). Changes to the elevational limits and extent of species ranges associated with climate change. Ecology letters, 8, 1138-1146.

Zhang, X., Zwiers, F. W., Hegerl, G. C., Lambert, F. H., Gillett, N. P., Solomon, S., . . Nozawa, T. (2007). Detection of human influence on twentieth-century precipitation trends. Nature, 448, 461.

This article is protected by copyright. All rights reserved 


\section{TABLES}

Table 1. General features of the study areas and monitored sites. Study areas correspond to the French Guiana coast (FG) and the southern Pantanal wetlands in the state of Mato Grosso do Sul, Brazil (BR). Weather conditions (Fick \& Hijmans, 2017), level of precipitation and thermal extremity within each species range ( $\mathrm{Pp}=$ Pseudis paradoxa; $\mathrm{Br}=$ Boana raniceps $)$, geographic coordinates and monitoring period are shown. Boana raniceps is absent at sites FG1 and FG2.

Table 2. Calling activity of Pseudis paradoxa and Boana raniceps in sites from the French Guiana coast (FG) and the southern Pantanal wetlands in Brazil (BR). Species activity was recorded by passive acoustic monitoring and detected with a semi-automated procedure of signal recognition.

Table 3. Relative humidity (\%) and temperature $\left({ }^{\circ} \mathrm{C}\right)$ during calling behaviour of two widespread Neotropical frogs. Data were compiled from seven populations of Pseudis paradoxa and five populations of Boana raniceps monitored in the French Guiana coast (FG) and the southern Pantanal wetlands in Brazil (BR). Weather conditions are shown separately for: (i) the entire monitoring period at night, one hour before sunset to one hour before sunrise, when species could potentially exhibit calling behaviour (potential); and (ii) when calling or (iii) chorusing behaviour was actually recorded.

Table 4. Regression coefficients and standard errors from generalized linear mixed-effects models on calling humidity and calling temperature. Models included localities (the French Guiana coast, FG; and the southern Pantanal wetlands in Brazil, BR) and species (Pseudis paradoxa, Pp; and Boana raniceps, $\mathrm{Br}$ ) as fixed factors, and sites, nights and hours as random factors. Reference values are based on $\mathrm{Br}$ and BR. Lower and Upper CL correspond to the confidence intervals of GLMM coefficients obtained through 1,000 bootstrap iterations.

\section{FIGURES}

Figure 1. Annual precipitation across the distribution range of Pseudis paradoxa $(\mathrm{a}, \mathrm{b})$ and Boana raniceps (c, d). Arrows on the histograms show the annual precipitation (mm, Fick \& Hijmans, 2017) in the two study areas: the French Guiana coast (FG) and the southern Pantanal wetlands in Brazil (BR). Dashed lines indicate the average annual precipitation of each species range (IUCN et al., 2008a; IUCN et al., 2008b).

Figure 2. Annual mean temperatures across the distribution range of Pseudis paradoxa (a, b) and Boana raniceps (c, d). Arrows on the histograms show the annual mean temperature $\left({ }^{\circ} \mathrm{C}\right.$, Fick \& Hijmans, 2017) in the French Guiana coast (FG) and the southern Pantanal wetlands in Brazil (BR). Dashed lines show the average annual mean temperature of each species range (IUCN et al., 2008a; IUCN et al., 2008b).

This article is protected by copyright. All rights reserved 
Figure 3. Habitat characterization and distribution of study sites in areas located at the humidity extremes of the distribution range of Pseudis paradoxa and Boana raniceps, namely the French Guiana coast (a) and the southern Pantanal wetlands in Brazil (b).

Figure 4. Relative humidity and temperature during calling activity of Pseudis paradoxa (a, c) and Boana raniceps (b, d) from sites in the French Guiana coast (FG1-4) and the southern Pantanal wetlands in Brazil (BR1-3). Boxplots represent median (horizontal line), 1st-3rd quartile range (box), and range (whiskers). Squares (FG) and diamonds (BR) depict average calling humidity and temperature for each study area. Grey rectangles represent the total breadth of relative humidity $(a, b)$ and temperature $(c, d)$ during the nights of the breeding season.

Figure 5. Daily calling activity, potential relative humidity (a-d) and potential temperature (e-h) in monitored populations of Pseudis paradoxa (first and third row) and Boana raniceps (second and fourth row) from the French Guiana coast (FG, left panels) and the southern Pantanal wetlands in Brazil (BR, right panels). Boxplots represent median (horizontal line), 1st-3rd quartile range (box), and range (whiskers) of relative humidity (a-d) and temperature (e-h). Dashed lines depict mean calling humidity or mean calling temperatures in FG (long-dashed) and BR (short-dashed). Calling activity is represented by the hourly average of the maximum Amphibian Calling Index (maxACI; based on an adapted version of the index ranging from 0 to 5 , see Methods) and its standard deviation. Grey rectangles highlight the relative humidity and temperature at the peak of calling activity. 
(a)

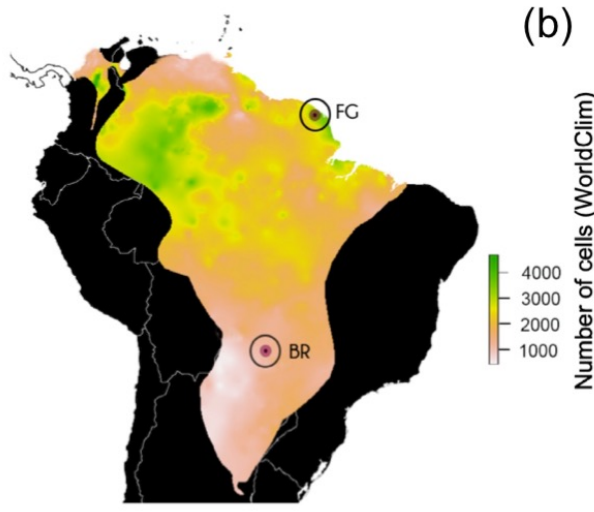

(c)

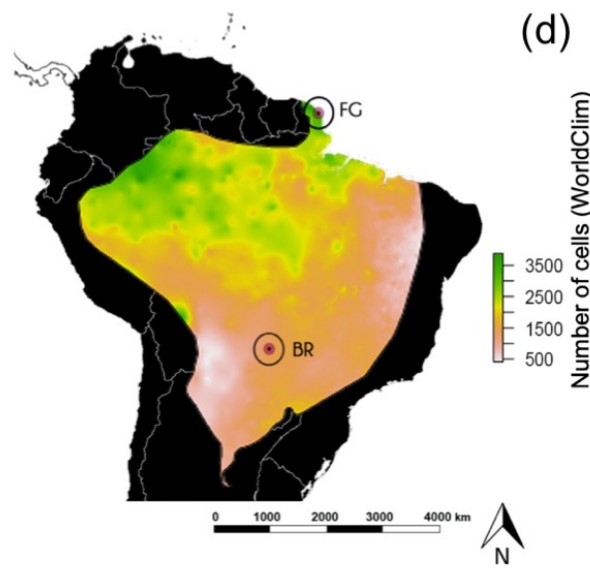

(d)
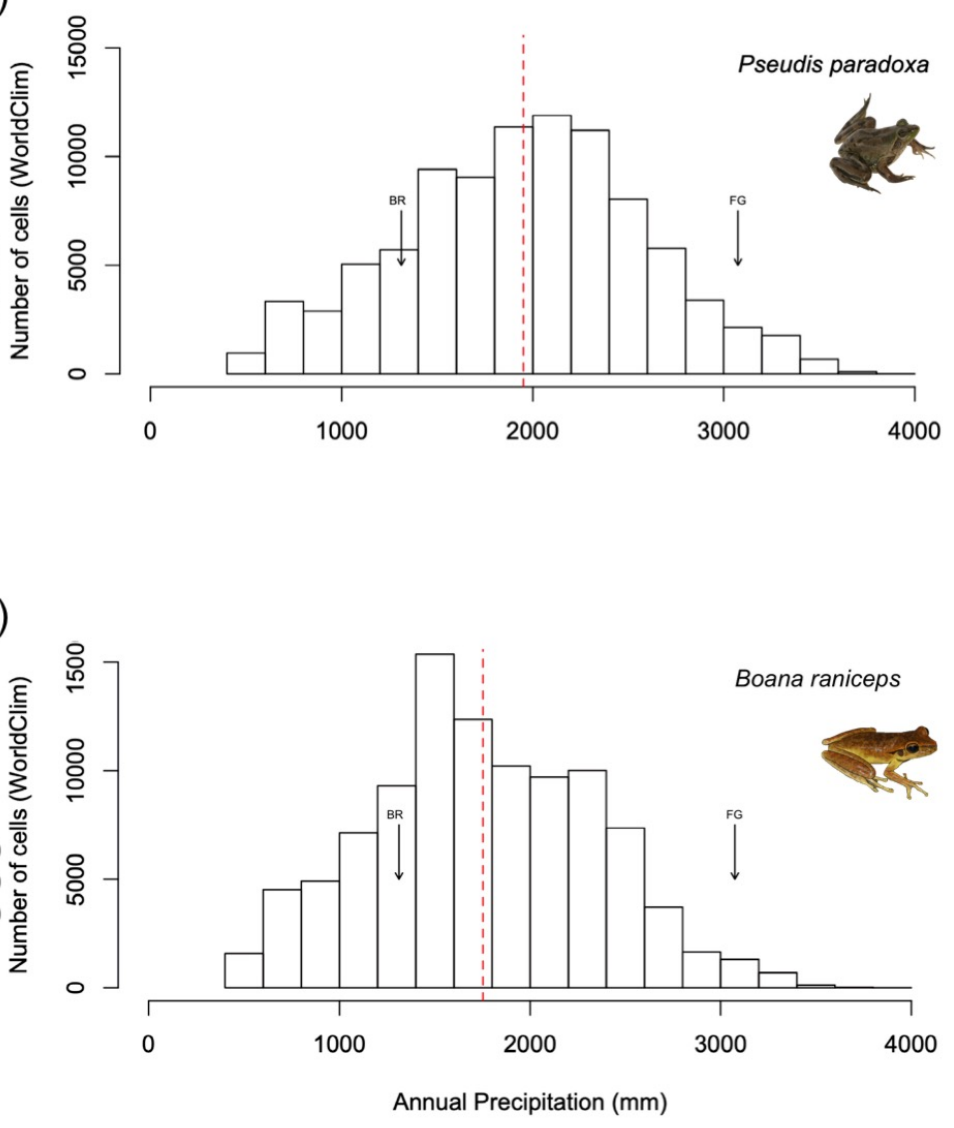
(a)

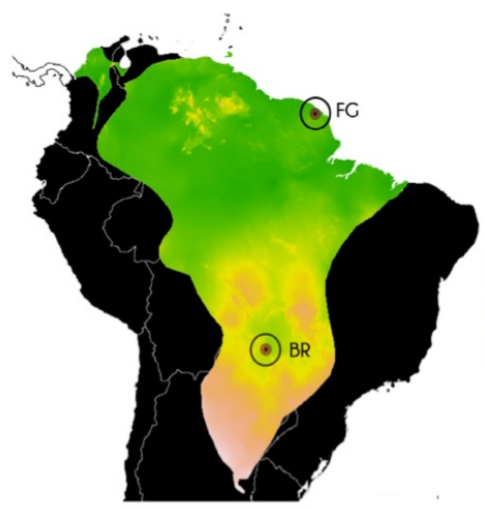

(c)

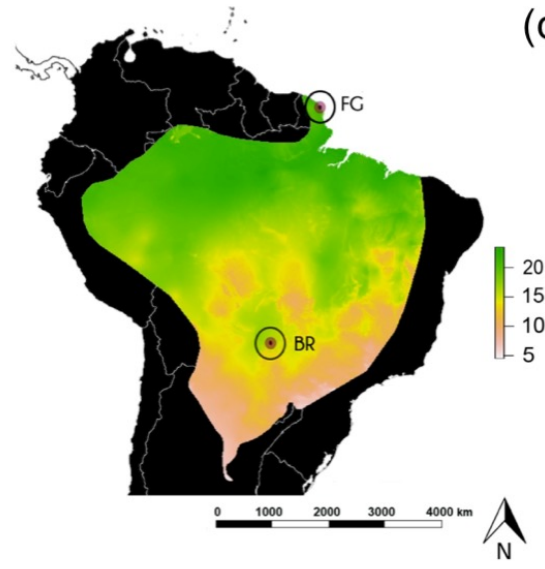

(b)

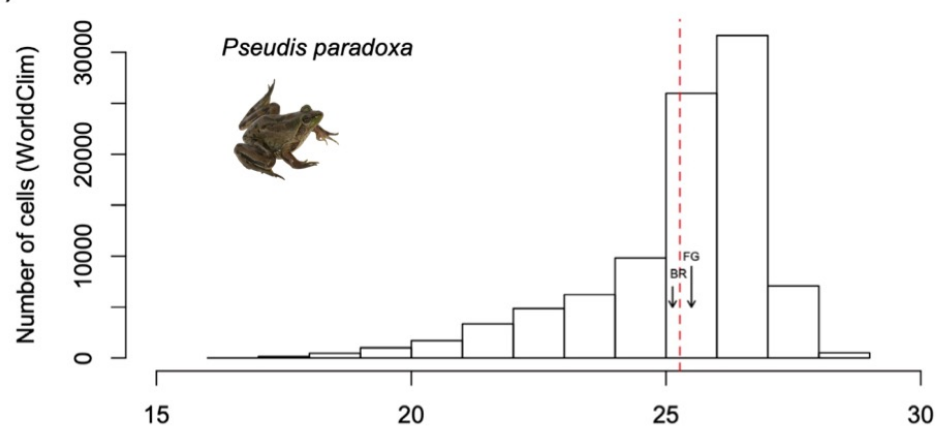

(d)

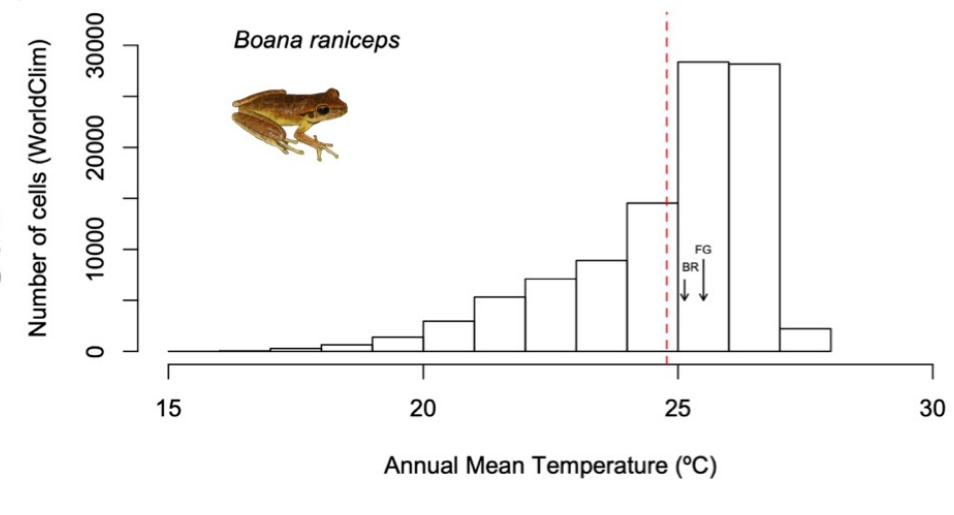


(a)

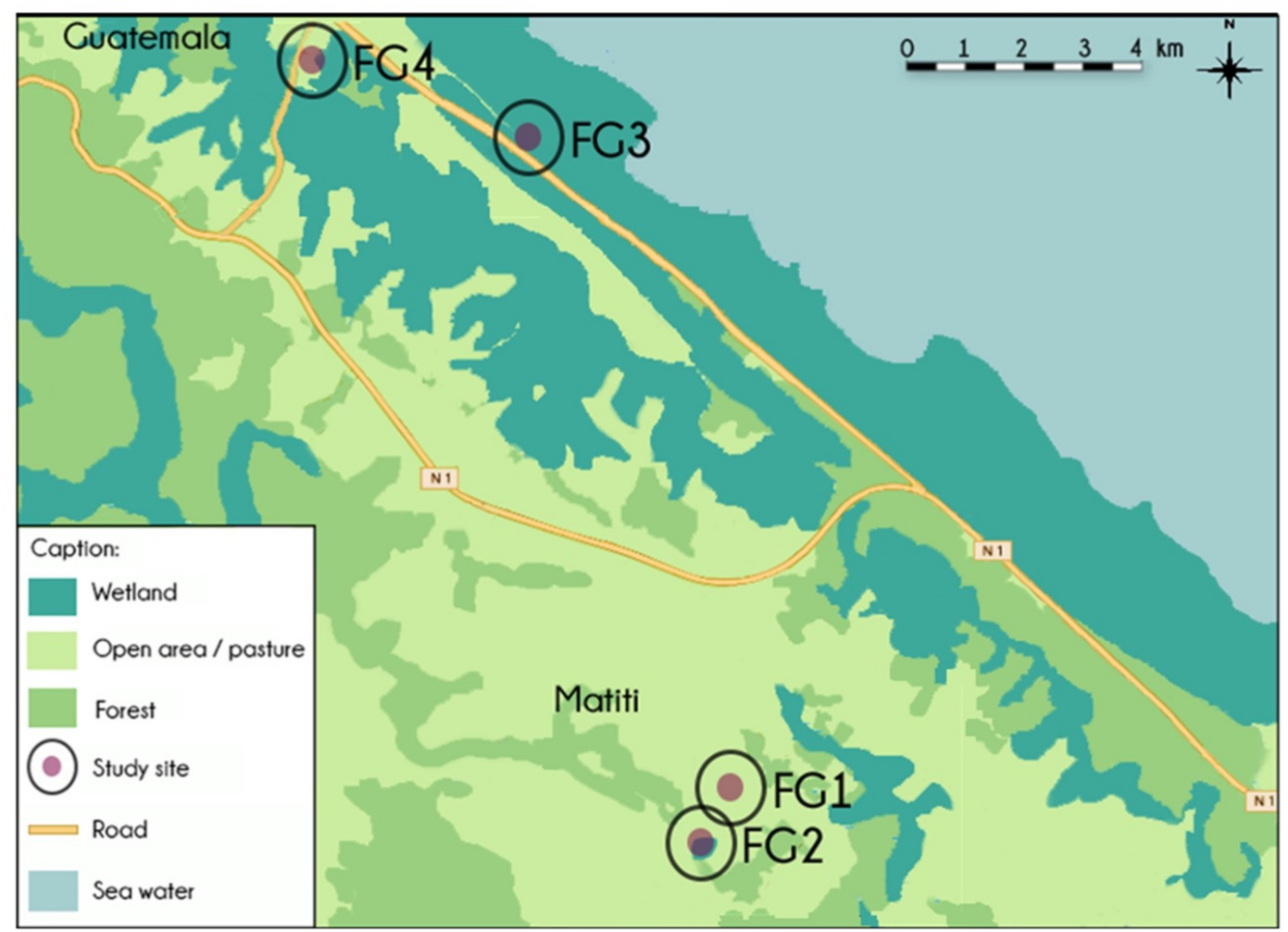

(b)

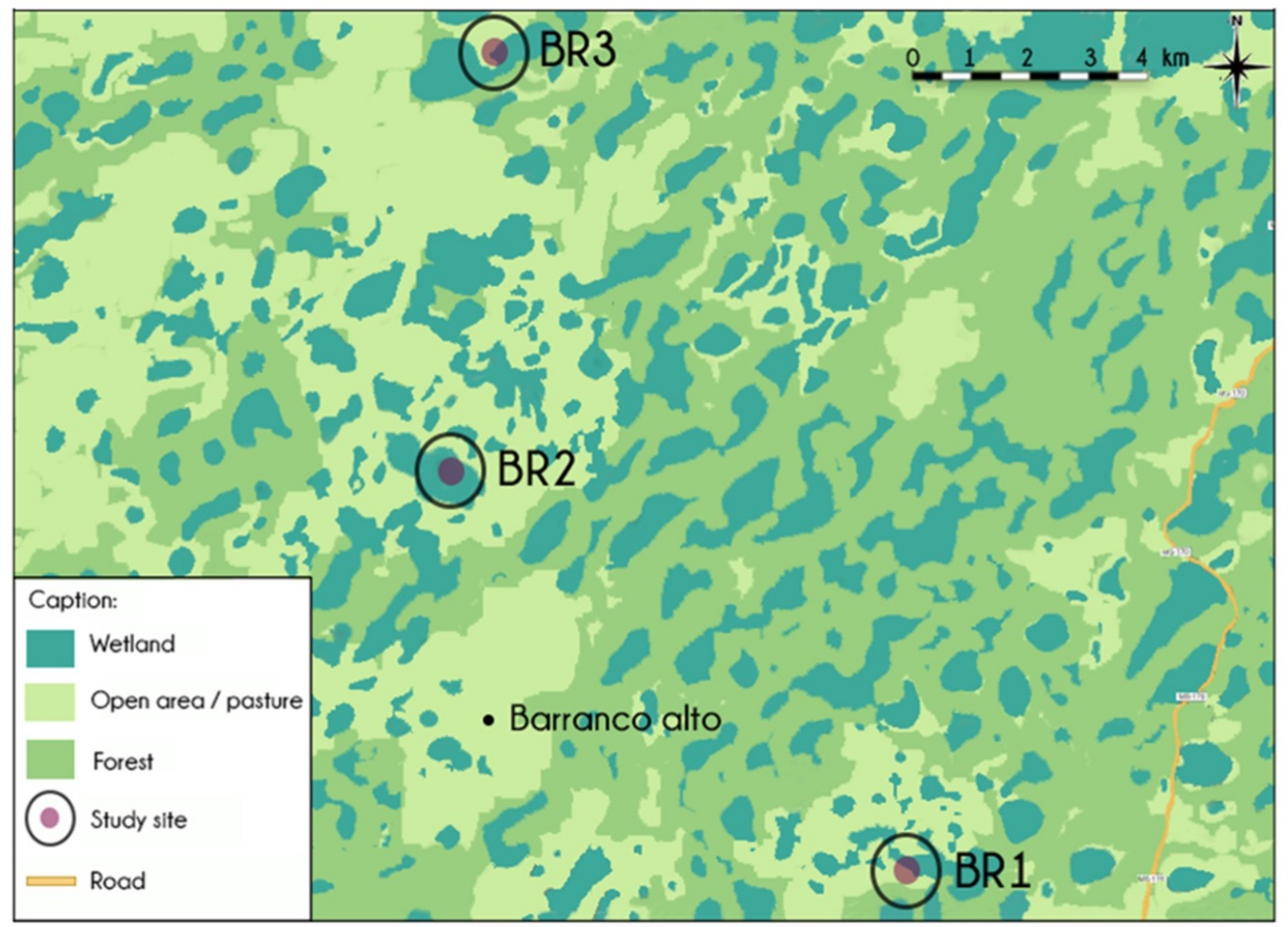


(a)

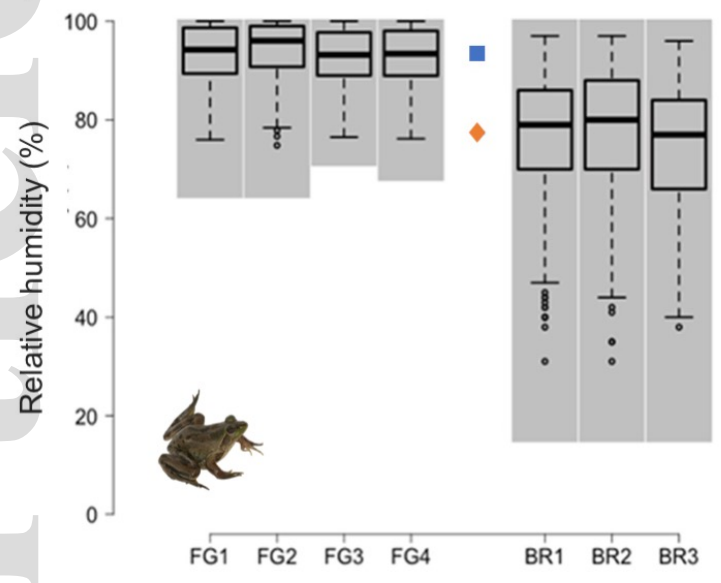

(c)

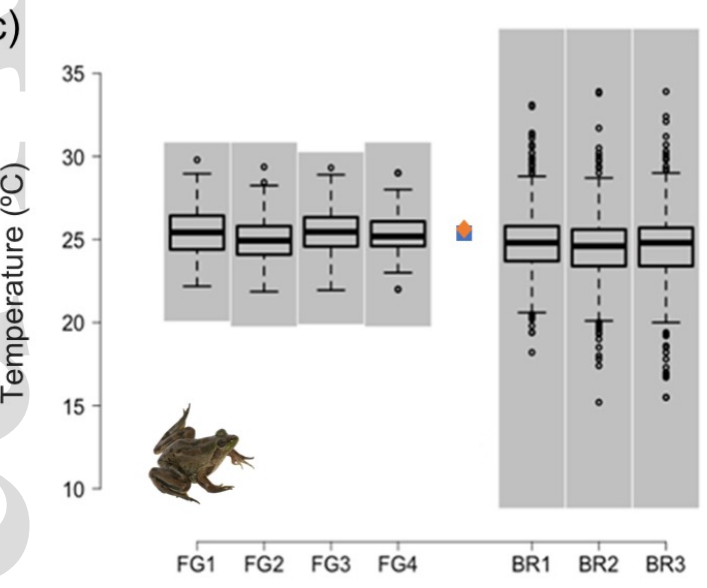

(b)

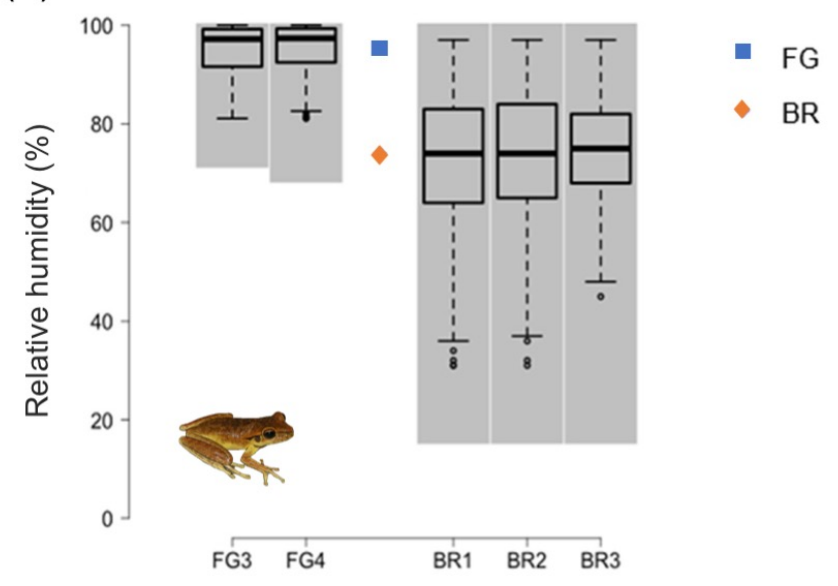

(d)

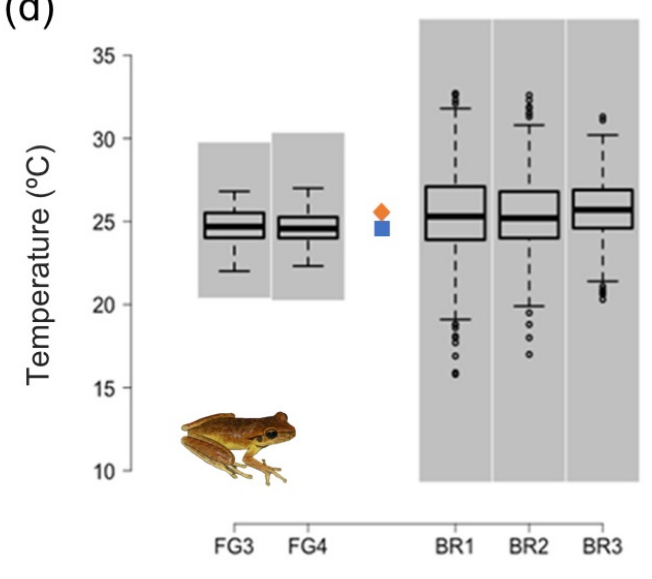


(a)

Humid extreme (FG)

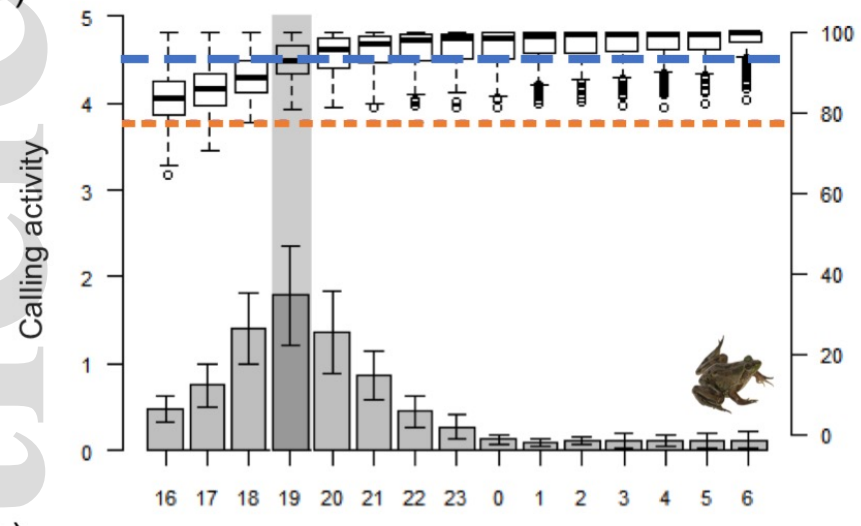

(c)

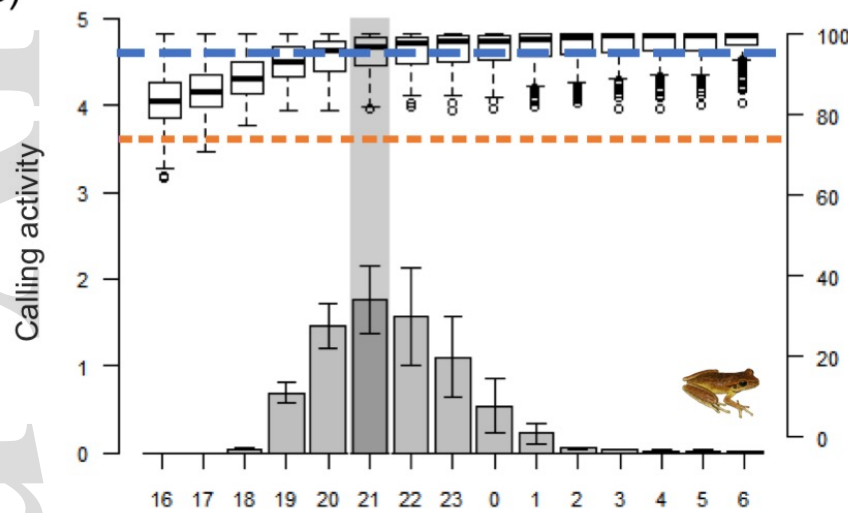

(e)

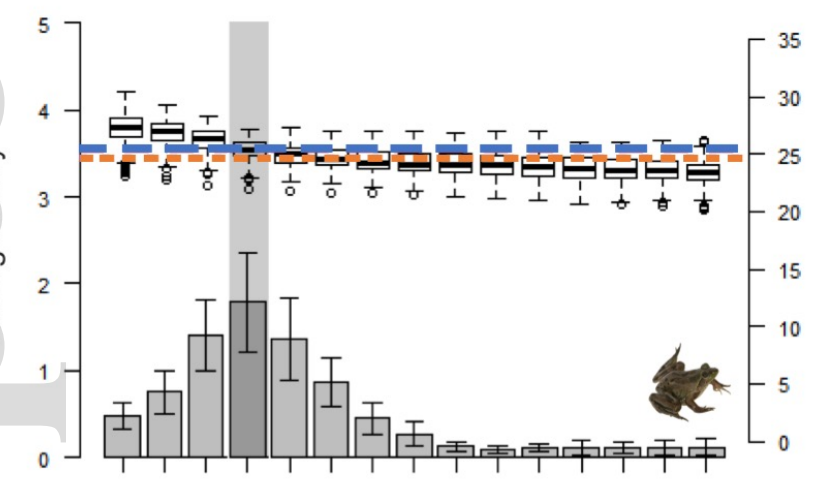

(g)

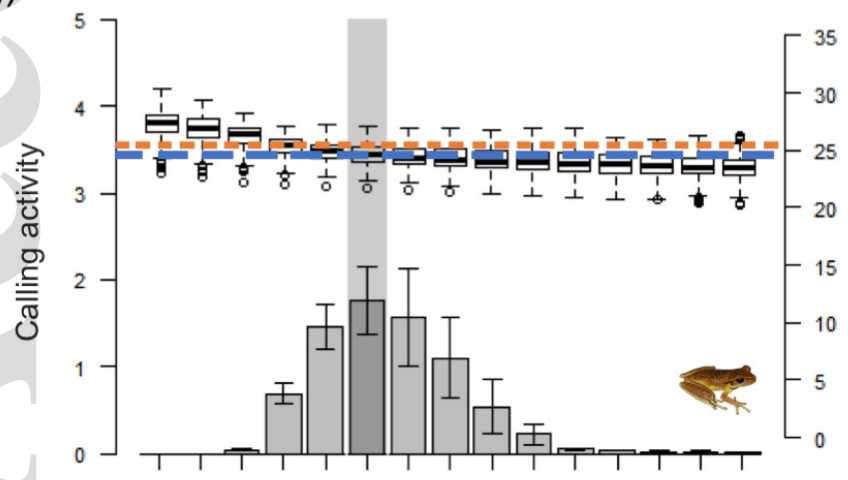

$\begin{array}{lllllllllllllll}16 & 17 & 18 & 19 & 20 & 21 & 22 & 23 & 0 & 1 & 2 & 3 & 4 & 5 & 6\end{array}$

Hours of the day (b)

Dry extreme (BR)

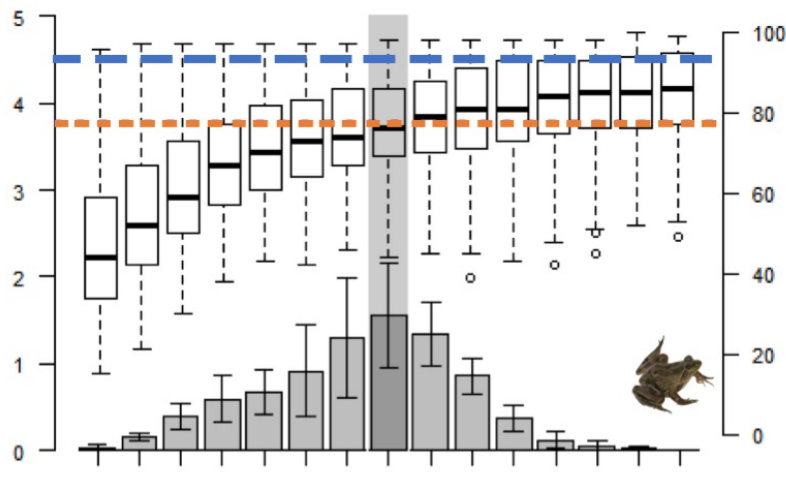

(d)
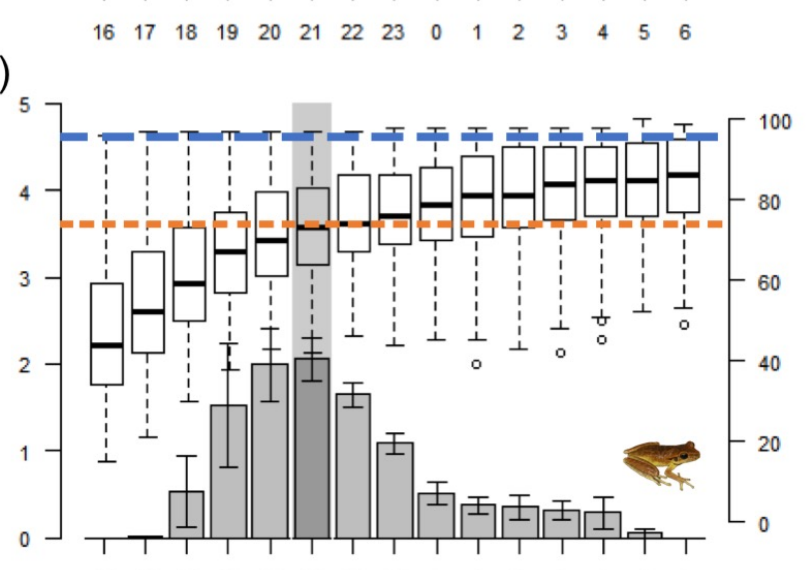

(f)

$\begin{array}{lllllllllllllll}16 & 17 & 18 & 19 & 20 & 21 & 22 & 23 & 0 & 1 & 2 & 3 & 4 & 5 & 6\end{array}$

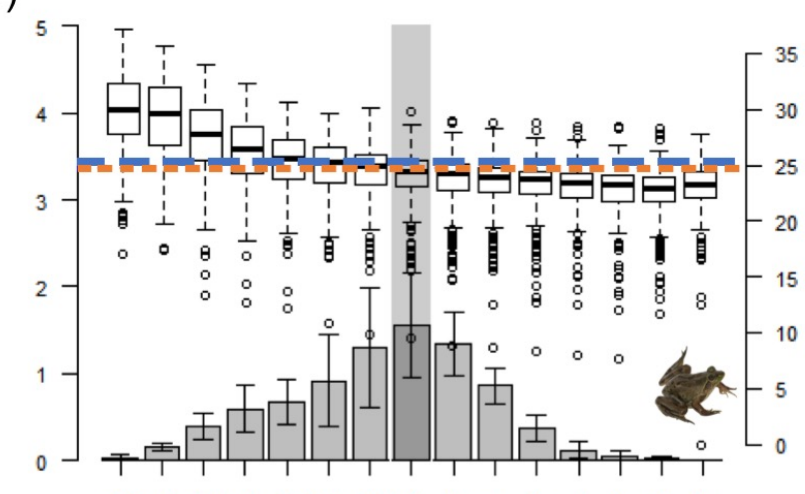

(h)
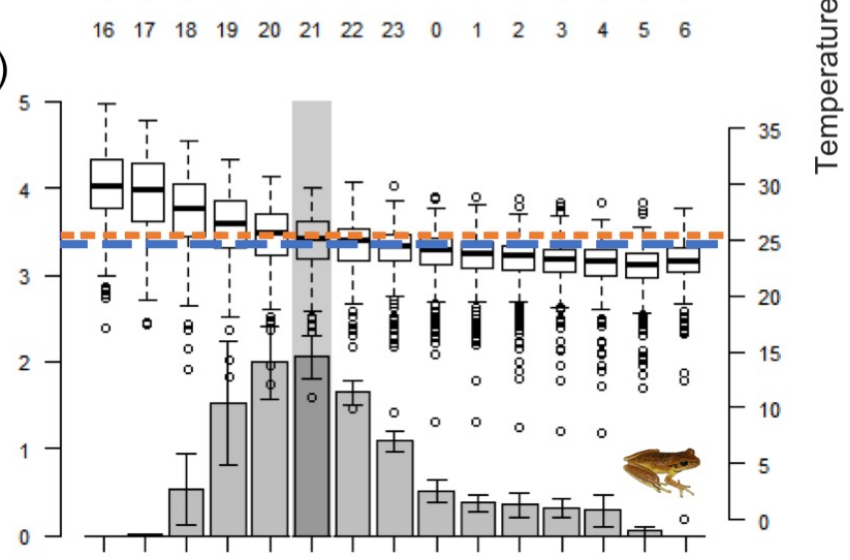

$\begin{array}{lllllllllllllll}16 & 17 & 18 & 19 & 20 & 21 & 22 & 23 & 0 & 1 & 2 & 3 & 4 & 5 & 6\end{array}$

Hours of the day

ণิํํ 峁

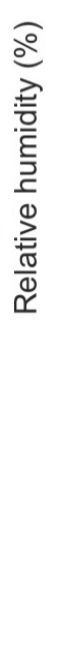

gcb_15266_f5.jpeg

This article is protected by copyright. All rights reserved 